\title{
MIRS: an AI scoring system for predicting the prognosis and therapy of breast cancer
}

(3)

4

5

\author{
Chen Huang ${ }^{1,3 \dagger}$, Min Deng ${ }^{2 \dagger}$, Dongliang Leng ${ }^{2 \dagger}$, Elaine Lai-Han Leung ${ }^{1,3}$, \\ Baoqing Sun ${ }^{4}$, Peiyan Zheng ${ }^{4}$, Xiaohua Douglas Zhang*
}

${ }^{1}$ Dr. Neher's Biophysics Laboratory for Innovative Drug Discovery, Macau

University of Science and Technology, Macau, SAR, China

${ }^{2}$ CRDA, Faculty of Health Sciences, University of Macau, Taipa, Macau

${ }^{3}$ Stat Key laboratory of Quality Research in Chinese Medicine, Macau Institute For Applied Research in Medicine and Health, Macau University of Science and Technology, Macau, SAR, China

${ }^{4}$ Department of Allergy and Clinical Immunology, State Key Laboratory of Respiratory Disease, National Clinical Research Center of Respiratory Disease, Guangzhou Institute of Respiratory Health, First Affiliated Hospital of Guangzhou Medical University, Guangzhou, Guangdong, China 8 ${ }^{\dagger}$ These authors contributed equally to this work *Correspondence: Xiaohua Douglas Zhang douglaszhang@um.edu.mo

NOTE: This preprint reports new research that has not been certified by peer review and should not be used to guide clinical practice. 
medRxiv preprint doi: https://doi.org/10.1101/2021.12.16.21267775; this version posted December 17, 2021. The copyright holder for this preprint (which was not certified by peer review) is the author/funder, who has granted medRxiv a license to display the preprint in

All rights reserved. No reuse allowed without permission.

\section{Abstract}

Current scoring systems for prognosis of breast cancer are available but usually consider only one prognostic feature. We aim to develop a novel prognostic scoring system based on both immune-infiltration and metastatic features to not only assess the patient prognoses more accurately but also guide therapy for patients with breast cancer.

Computational immune-infiltration and gene profiling analysis identified a 12-gene panel firstly characterizing immune-infiltrating and metastatic features. Neural network model yielded a precise prognostic scoring system called metastatic and immunogenomic risk score (MIRS). The influence of MIRS on the prognosis and therapy of breast cancer was then comprehensively investigated. MIRS significantly stratifies patients into high risk-group (MIRS ${ }^{\text {high }}$ ) and low risk-group (MIRS ${ }^{\text {low }}$ ) in both training and test cohorts. The MIRS ${ }^{\text {low }}$ patients exhibit significantly improved survival rate compared with MIRS ${ }^{\text {high }}$ patients. A series of analyses demonstrates that MIRS can well characterize the metastatic and immune landscape of breast cancer. Further analysis on the usage of MIRS in chemotherapy suggests that MIRS ${ }^{\text {high }}$ patients may benefit from three chemotherapeutic drugs (Cisplatin, Tamoxifen and Vincristine). Higher immune infiltration and significantly prolonged survival are observed in MIRS ${ }^{\text {low }}$ patients, indicating a better response in immune checkpoint inhibitor therapy. Our analysis demonstrates that MIRS could effectively improve the accuracy of prognosis for patients with breast cancer. Also, MIRS is a useful webtool, which is deposited at https://lva85.github.io/MIRS/, to help clinicians in designing personalized therapies for patients with breast cancer. 
medRxiv preprint doi: https://doi.org/10.1101/2021.12.16.21267775; this version posted December 17, 2021. The copyright holder for this preprint (which was not certified by peer review) is the author/funder, who has granted medRxiv a license to display the preprint in

All rights reserved. No reuse allowed without permission.

44

45

46

47

48

Keywords: Breast cancer, Metastasis, Immune infiltration, Prognosis, Personalized treatment

\section{Introduction}

Cancer has long history in mankind and remains the leading cause of death, with breast cancer being one of the most common malignancies in women worldwide $(1,2)$. Breast cancer is also the second most common cause of death in cancer-related deaths among women. $(3,4)$. Despite tremendous advancement of medicine over the years has lowered the mortality rate, the high level of heterogeneity in breast cancer still makes the prognosis and treatment challenging.

Over the decade, a considerable amount of work has been done to develop prognostic measures on the progression of breast cancer (5). The majority ( 80\%) of breast cancer becomes invasive (6) and approximately $20 \sim 30 \%$ of them results in distant metastasis after treatment (7). Metastasis is thereby the most fatal development of breast cancer, which greatly reduces the rate of long-term survival from $90 \%$ to $5 \%$ (8). However, most metastasis-based signatures were developed based on organspecific metastatic events, yet breast cancer consists of tumors with extremely heterogeneous cell types, resulting in the discrepancy between prognosis and survival $(9,10)$. Hence currently available metastasis-based prognostic measures have poor performance (11). On the other side, tumor-infiltrating lymphocytes have already been reported to be inextricably linked to therapeutic efficacy and patient survival in various cancers $(12,13)$. Many prognostic predictors were developed by assessing the level of 
medRxiv preprint doi: https://doi.org/10.1101/2021.12.16.21267775; this version posted December 17, 2021. The copyright holder for this preprint (which was not certified by peer review) is the author/funder, who has granted medRxiv a license to display the preprint in

All rights reserved. No reuse allowed without permission.

65

the infiltration of immune cells into tumor and were preferably adopted for prognosis in cancers $(14,15)$. These histological strategies based on the analysis of a small proportions of immune cell marker genes support the prognostic significance of immune infiltration but still have limitations. Firstly, strategies for describing the level of immune infiltrate are the first limitation of the current studies (16). Specifically, each immune cell subset is computationally estimated by reference profiles based on bulk analysis of tissue samples. This is the main drawback because the transcriptional program of immunocytes exhibits high plasticity under tumor microenvironments (17). Secondly, while most studies were used the immune-related characteristics to improve cancer prognosis, only one or two subsets of immunocyte are included and these subsets lack functional variation, thus the treatments based on these indicators fail to achieve satisfactory immune response effects (18). Therefore, prognostic indicator based on only one characteristic without considering other crucial features is insufficient to accurately assess risk stratification and direct treatment strategies.

Given the limitations of the aforementioned work a more comprehensive approach should be developed to assess prognostic value and translate it into clinical practice. For the first time, we develop a prognostic signature for breast cancer patients, integrating immune-related gene signatures involved in metastasis, to classify patients with breast cancer into groups of high and low risk for potential therapeutic strategies. We construct a Neuron network to estimate gene weights, which exhibit outstanding performance in binary classification. A metastatic and immunogenomic risk score (MIRS) is then established, which has conspicuous power to predict survival status 
medRxiv preprint doi: https://doi.org/10.1101/2021.12.16.21267775; this version posted December 17, 2021. The copyright holder for this preprint (which was not certified by peer review) is the author/funder, who has granted medRxiv a license to display the preprint in

All rights reserved. No reuse allowed without permission.

87

88

89

90

91

92

93

94

95

96

97

compared with previously published indicators based on single feature. Ultimately, the ability of MIRS to predict the treatment is identified, suggesting its potential to guide therapeutic tactics in breast cancer.

\section{Collection and pre-processing of breast cancer data}

collected from Gene Expression Omnibus (GEO), The Cancer Genome Atlas (TCGA, https://www.cbioportal.org/datasets), and Molecular Taxonomy of Breast Cancer International Consortium (METABRIC, https://www.cbioportal.org/datasets). Only the datasets available with sufficient overall survival information were included, consisting of 8,424 patients from 14 cohorts. The detailed information of each cohort is presented in Table S1 and S2.

Raw series matrix files generated by Affymetrix were downloaded from GEO database. The R package GEOquery (19) was used to process raw matrix data. Duplicated genes detected by multiple probes were retained by taking the maximum expression value of the probe sets. Gene expression value was normalized by $\log _{2}$ transformation. Each GEO and RNA-seq dataset were processed independently.

\section{Construction of immune cell infiltration groups}

A set of biomarkers is derived from Charoentong et al (20), comprising 45 immune signatures related to immune cell types, immunogenomic pathways and functions. The 
medRxiv preprint doi: https://doi.org/10.1101/2021.12.16.21267775; this version posted December 17, 2021. The copyright holder for this preprint (which was not certified by peer review) is the author/funder, who has granted medRxiv a license to display the preprint in

All rights reserved. No reuse allowed without permission.

107

108

109

110

111

112

113

114

115

116

concrete gene signatures for each immune cell type were obtained from (21), and the immune-related pathways and functions were downloaded from database 'ImmPort' (22). Single sample gene set enrichment analysis (ssGSEA) implemented in R package GSVA was used to quantify the infiltration level of different immune cells, immunogenomic pathways and the activity of immune-related functions via expression data of breast cancer (23). Based on the results of ssGSEA, patients in TCGA breast cancer cohort (TCGA-BRCA) were divided into high and low immune cell infiltration groups using hierarchical clustering analysis (Figure S1) (24).

\section{Identification of immune and metastatic candidate}

\section{genes}

Using Wilcoxon rank-sum (Wilcoxon) test, the differentially expressed genes (DEGs) related to tumor immune infiltration were detected from high and low immune infiltration conditions according to the filtering criteria $|\log 2 \mathrm{FC}|>0.5$ and adjusted $\mathrm{p}<$ 0.05 using Benjamini and Hochberg (BH) method (25). Meanwhile, utilizing the Wilcoxon test with the same criteria in the comparison between metastasis and primary breast cancer groups from the union of GSE10893 and GSE3521, the DEGs involved in metastatic mechanism were then identified. For these two DE analyses, Venn analysis found 52 metastatic and immunogenomic candidate genes. The heatmap of these DEGs are visualized in Supplementary Figures S3-S4. 
medRxiv preprint doi: https://doi.org/10.1101/2021.12.16.21267775; this version posted December 17, 2021. The copyright holder for this preprint (which was not certified by peer review) is the author/funder, who has granted medRxiv a license to display the preprint in

All rights reserved. No reuse allowed without permission.

\section{Establishment of prognostic risk score}

Univariate Cox proportional hazard regression analysis was designed to screen

features related to overall survival (OS) from 52 candidate genes in TCGA BRCA

cohort. The filtered gene list is provided in Table S2. Subsequently, only the genes with

absolute Hazard ratio (HR) larger than 1 and p-value less than 0.05 were retained. To

eliminate collinearity, the eligible candidate genes were further filtered depending on

the criteria that the square root of Variance Inflation Factor (VIF) was less than 2 and

the Pearson Correlation Coefficient was smaller than 0.5. Ultimately, 12 prognostic

genes that were significantly correlated with patients' OS were identified.

These 12 prognostic signatures were classified into binary status. One was defined

as the protective status in which HR was less than 1 whereas another was the dangerous

status in which the corresponding HR was greater than 1 . The expression status of each

protective mRNA was assigned as 1 if the expression level of this mRNA was above

the median of the expression values of all samples, otherwise it would be assigned as

0 . In contrast, the expression of dangerous mRNA was assigned as 1 if it had expression

value below median, otherwise assigned as 0 . This approach not only allows the risk 
medRxiv preprint doi: https://doi.org/10.1101/2021.12.16.21267775; this version posted December 17, 2021. The copyright holder for this preprint (which was not certified by peer review) is the author/funder, who has granted medRxiv a license to display the preprint in

All rights reserved. No reuse allowed without permission.

$W_{12,1} i_{12}+b_{1}$ was defined, where $W$ is the weight of each input node and $i_{j}(j=$ $1,2, \ldots, 12)$ is the ' $0-1$ ' status of gene. Then we exploited rectified linear unit (ReLU):

and $n e t_{01}=W_{1,1}^{\prime} * O u t_{n 1}+W_{2,1}^{\prime} * O u t_{n 2}+W_{3,1}^{\prime} * O u t_{n 3}+W_{4,1}^{\prime} * O u t_{n 4}+b_{2}$ as an activation function in the hidden layer. In the output layer, we applied the Softmax function to each node and designated probability of death:

$$
\operatorname{softmax}\left(\text { net }_{01}\right)=\text { Out }_{01}=\frac{e^{n e t_{01}}}{e^{n e t_{01}}+e^{n e t_{02}}} \in(0,1) .
$$

We then created two nodes $a_{0}=0$ and $a_{1}=1$ for alive and dead, respectively. Cross entropy error is computed as:

$$
E=\sum_{i=1}^{N} E_{i}=-a_{0}^{i} * \log \left(o u t_{01}^{i}\right)-a_{1}^{i} * \log \left(o u t_{02}^{i}\right), \quad \text { where } i \text { is ith sample. }
$$

Finally, the value of each weight was optimized by minimizing $E$ using gradient descent. The R packages Tensorflow and Keras were employed to construct neuron network. After training, the coefficient of each prognostic gene was then determined as the maximum weight in the hidden layer (26).

Lastly, the risk score that consists of 12 metastatic and immunogenomic prognostic genes (MIRS) for each patient is defined as the following:

$M I R S_{i}=\sum_{j=1}^{m}$ weight $_{j} \times I_{\{\text {protective gene } j\}}+\sum_{k=1}^{n}$ weight $_{k} \times I_{\{\text {dangerous gene } k\}}$ where $m$ and $n$ denote the number of protective and dangerous genes, respectively, weight is the maximum weight from the hidden layer. Additionally, $I_{\{\text {protective gene } j\}}$ and $I_{\{\text {dangerous gene } k\}}$ denote the following indicator functions:

$I_{\{\text {protective gene }}$ $= \begin{cases}1, & \text { Protective gene } j<\text { Median expression value across all samples, } \\ 0, & \text { otherwise. }\end{cases}$ 
medRxiv preprint doi: https://doi.org/10.1101/2021.12.16.21267775; this version posted December 17, 2021. The copyright holder for this preprint (which was not certified by peer review) is the author/funder, who has granted medRxiv a license to display the preprint in

All rights reserved. No reuse allowed without permission.

172

173

174

$I_{\{\text {dangerous gene } j\}}$

$= \begin{cases}1, & \text { Dangerous gene } \mathrm{k}>\text { Median expression value across all samples, } \\ 0, & \text { otherwise. }\end{cases}$

\section{Statistical analysis}

All statistical analyses were performed using R software. The R packages pheatmap and ggplot 2 were used to plot heatmap and other graphs. The R package forestplot was used to draw forest plot. The pROC package was employed to generate the Receiver Operating Characteristic (ROC) curve and calculate the Area Under Curve (AUC), which was an indicator to evaluate the predictive performance of risk score.

Based on the risk score, breast cancer patients in the investigated cohort were stratified into subtypes of high risk or low risk depending on whether the value of (MIRS in each patient)/(median of MIRS in all patients) was greater or less than 1 . This stratification method allows reasonable comparisons between different data platforms. OS curves were established by Kaplan-Meier survival (KM) curve function ggsurvplot, as implemented in R package survminer, and the difference in survival distributions between risk subgroups was estimated by two-side log-rank test.

Based on univariate Cox proportional hazard regression analysis, the targeted prognostic genes which were significantly correlated with OS were disclosed and the Hazard ratio (HR), 95\% confident interval of HR and p-value were also evaluated. Multivariate Cox proportional hazard regression model was implemented to assess whether the risk score is an independent prognosis factor when compared with other important clinical features. All statistical tests were considered significant with p-value 
medRxiv preprint doi: https://doi.org/10.1101/2021.12.16.21267775; this version posted December 17, 2021. The copyright holder for this preprint (which was not certified by peer review) is the author/funder, who has granted medRxiv a license to display the preprint in

All rights reserved. No reuse allowed without permission.

193

194

195

196

197

$<0.05$.

Full details about data and methods descriptions, including data information, gene set enrichment analysis and mutation landscape analysis.

\section{Results}

\section{Screening of candidate genes from three public datasets}

To obtain significant prognostic biomarkers in breast cancer, we proposed a systematic scheme of bioinformatic analysis (Figure 1). Given that the processes of metastasis and immune infiltration in tumor play various important roles in cancer development, we hypothesize that the expression of genes which were associated with metastasis and immune infiltration in tumor should be correlated to the OS of cancer patients. We thereby identified prognostic signatures based on these two characteristics. Concretely, using ssGSEA method, the expression profile of 1,100 patients from TCGA cohort were used to construct groups of high and low immune cell infiltration. Then the patients were classified into the high immune infiltration group and low immune infiltration group (Figure 2A and Figure S1). Furthermore, to validate the reliability of the above grouping tactic, we investigated the expression level of two immune-related gene families between these two groups: $C D 1$ and ILI. As expected, the expression of both immune-related gene families in the high immune infiltration group is significantly higher than that in the low immune infiltration group (Figure 1B and Figure S5). Additionally, compared with low immune cell infiltration group, high immune cell infiltration group exhibits a higher fraction of immune cell, stromal cell 
medRxiv preprint doi: https://doi.org/10.1101/2021.12.16.21267775; this version posted December 17, 2021. The copyright holder for this preprint (which was not certified by peer review) is the author/funder, who has granted medRxiv a license to display the preprint in All rights reserved. No reuse allowed without permission.

214 but lower tumor purity using ESTIMATE (28) algorithm (Figure 2C). Furthermore, we 215 found that high immune cell infiltration group had significantly higher proportions in most immune cell types than low immune infiltration group (Figure 2D) using

217 CIBERSORT algorithm under the permutation test with 1000 times. These findings 218 support that our immune cell infiltration grouping is highly confident to be used in 219 downstream analyses. Next, 1,222 differentially expressed genes were identified via differential expression (DE) analysis between these two groups, which represents a high-confidence dataset of genes related to immune infiltration (Table S4).

On the other part, aimed at identification of metastasis-related candidates, DE analysis between metastasis and primary patients with breast cancer were performed using two GEO cohorts (GSE10893 and GSE3521). The reason why we only chose these two GEO datasets is that they have relatively balanced sample sizes between the metastasis and primary groups when compared with other cohorts (Table S1). For instance, TCGA breast cancer cohort contains 1,165 primary individuals but only 23 metastatic individuals. There is no doubt that such an extremely imbalanced data would lead to biased result in DE analysis. This step yielded a union of 2,159 DE genes from the results of these two GEO datasets (Table S4). Finally, a total of 52 genes was obtained by intersecting 1,222 immune-infiltration-related genes and 2,159 metastasisrelated genes (Figure 2E), which represents prognostic candidates associated with both tumor-immune infiltration (Figure 2F) and metastasis (Figure 2G). 


\section{Construction and validation of MIRS in breast cancer 235 cohorts}

Univariate Cox regression analyses were performed to estimate the prognostic relationship between candidate genes and overall survival in TCGA cohort. Among these 52 candidate genes, 15 genes with p-value less than 0.05 were selected for followup study (Table S2). Given that too many redundant variables would result in overfitting in the linear model, we employed the analyses of Variance Inflation Factor and Pearson Correlation Coefficient to eliminate the redundant genes (Figure 3A and 3B). As a result, a panel of 12 genes is reserved to establish the predictive model. data $(\mathrm{N}=770$ patients $)$ and testing data $(\mathrm{N}=330$ patients $)$ at a ratio of $7: 3$. We then optimized the weights for each gene with Neuron network in the training TCGA data. The MIRS for each patient was built by summation of Weight $\times$ $247 I_{\{\text {protective or dangerous gene\} }}$ of all 12 genes (Table 1). MIRS was initially used to 248 predict patient's survival status, which yielded great predictive performance with AUC accuracy of 0.875 in the training TCGA cohort (Figure 3C). In addition, all the patients 250 were classified into $\mathrm{MIRS}^{\text {high }}$ group and $\mathrm{MIRS}^{\text {low }}$ group using the median value of 251 MIRS as risk cut-off. As shown in Figure 3D, patients in MIRS ${ }^{\text {low }}$ group had 252 significantly longer OS or disease-free survival (DFS) time than those in MIRS ${ }^{\text {high }}$ group (log-rank p<0.001) (Figure 3D and Figure S6-A). 
medRxiv preprint doi: https://doi.org/10.1101/2021.12.16.21267775; this version posted December 17, 2021. The copyright holder for this preprint (which was not certified by peer review) is the author/funder, who has granted medRxiv a license to display the preprint in

All rights reserved. No reuse allowed without permission.

256

257

258

259

260

261

262

263

264

265

266

267

268

269

270

271

272

273

274

275

276

testing cohorts. Notably, MIRS exhibited robust predictive capacity with AUC of 0.934 , 0.901, and 0.904 in GSE96058, GSE86166 and GSE20685, respectively (Figure 3E and

3G, Supplementary Figure S6-C). Regarding the survival analyses, consistent with the result of the training data, the patients who are divided into MIRS ${ }^{\text {high }}$ group have significantly worse OS than those in $\mathrm{MIRS}^{\text {low }}$ group (Figure 3F, Figure $3 \mathrm{H}$ and Supplementary Figure S6-B). These analyses indicated that MIRS had precisely prognostic ability in breast cancer. The higher score of MIRS corresponds to poor outcome, and the lower score of MIRS refers to favorable outcome.

\section{Correlation of MIRS with the metastatic and}

\section{immunogenomic landscape between the high and low}

\section{subtypes}

We want to further scrutinize the correlation of metastatic and immunogenomic landscape with MIRS in breast cancer patients. Initially, we investigated the correlation between MIRS and the fraction of immune cell, stromal cell, as well as tumor purity via ESTMATE in the GSE86166 cohort. The results showed that MIRS ${ }^{\text {low }}$ group had a higher fraction of immune cell and stromal cell cell but a lower tumor purity (Figure 4A). Similar situations were observed in GSE96058 (Figure S7). Reasonably, a higher fraction of immune cell and lower tumor purity reflects a high level of infiltrating Tlymphocytes in the patients of MIRS ${ }^{\text {low }}$ group, which is consistent with previous survival analysis.

Moreover, 730 genes were identified to be correlated to the 12 genes of MIRS 
medRxiv preprint doi: https://doi.org/10.1101/2021.12.16.21267775; this version posted December 17, 2021. The copyright holder for this preprint (which was not certified by peer review) is the author/funder, who has granted medRxiv a license to display the preprint in

All rights reserved. No reuse allowed without permission.

277 (Spearman Correlation Coefficient $\geqslant 0.4)$ using GSE86166, subsequently, functional

278 enrichment analysis achieved via METASCAPE, indicating various immune-related

279 processes and pathways were significantly enriched, including $\mathrm{T}$ cell activation,

280 Cytokine-cytokine receptor interaction and B cell activation (Figure 4B). This

281 observation discloses a strong correlation of MIRS with immune activity. Alternatively,

282 we applied ssGSEA analysis to evaluate the immune infiltration level in GSE86166

283 using 17 immune-related biological functions and pathways derived from the immune-

284 related database 'ImmPort' (22). The result illustrates that most of the 17 items show

285 significant difference between MIRS ${ }^{\text {high }}$ and MIRS ${ }^{\text {low }}$ group (Figure 4C). Notably, all

286 immune-related biological processes and pathways exhibit significantly higher level of

287 immune infiltration in $\mathrm{MIRS}^{\text {low }}$ group (Figure 4C), which is consistent with our

288 previous analysis. Moreover, we estimated the correlation of MIRS with three

289 important immune checkpoint molecules: PD-1, PD-L1 and CTLA4. As illustrated in

290 Figure 4E, compared with MIRS ${ }^{\text {high }}$ group, MIRS $^{\text {low }}$ group shows significantly higher

291 expression (Wilcoxon test $\mathrm{P}<0.0001$ ). MIRS scores are moderately correlated to the

292 expression levels of PD-1, PD-L1 and CTLA4 (Figure 4D). Overall, the differences in

293 tumor immunogenicity between the MIRS groups are significant, MIRS ${ }^{\text {high }}$ group has

294 relatively low immune infiltration level while MIRS $^{\text {low }}$ group has relatively high

295 immune infiltration level. Similar results were also observed in TCGA and GSE96058

296 cohort (Supplementary Figure S8). This finding further suggested MIRS ${ }^{\text {low }}$ group

297 maight have better response in therapy of immune checkpoint blockade.

298 To investigate the correlation between MIRS score and metastatic mechanism, we 
medRxiv preprint doi: https://doi.org/10.1101/2021.12.16.21267775; this version posted December 17, 2021. The copyright holder for this preprint (which was not certified by peer review) is the author/funder, who has granted medRxiv a license to display the preprint in

All rights reserved. No reuse allowed without permission.

299

300

301

302

303

304

305

306

307

308

309

310

311

312

313

314

315

316

317

318

319

320

firstly downloaded the metastasis breast cancer (METABRIC) cohort from human cancer metastasis database https://hcmdb.i-sanger.com/, which contains primary tumor and metastatic tumor. Then the functional analysis achieved by GSEA detects 23 qualified metastasis-related gene sets $(\mathrm{NES} \mid>1$, NOM $\mathrm{p}$-value $<0.05$ and FDR q-value $<0.25)$. After that, ssGSEA analysis was used to evaluate the above significant metastatic pathways. We observe that the metastatic pathways exhibit significant difference between two MIRS groups, and the majority of MIRS ${ }^{\text {high }}$ group had higher ssGSEA score (Figure 4G). A higher ssGSEA score suggests high activity of metastatic processes. Similar results are found in TCGA and GSE96058 cohort (Figure S9-S10). Furthermore, the expression discrepancy of three well-known genes (DCC, MMP9 and ETS) were found to be correlated to the invasion and metastasis in breast cancer (29) (Figure 4F), and MIRS exhibits moderately negative correlation with the expression of these genes (Figure 4H).

We also examined the relationship between intrinsic molecular subtypes and MIRS. In breast cancer, major subtypes based on the ER, PR and HER2 exist on tumor cells. As shown in Figure S15, although the expression levels of ER, PR and HER2 were moderately correlated with MIRS, the differences in the expression levels of ER, PR and HER2 between high and low MIRS subtypes were statistically significant in TCGA and GSE86166. Additionally, for TCGA cohort, we noticed the imbalanced proportions of intrinsic molecular subtypes between MIRS ${ }^{\text {high }}$ and MIRS ${ }^{\text {low }}$ groups (Figure 4I). $48.09 \%$ of LumA tumor and $22.5 \%$ of Normal-like tumor are present in MIRS ${ }^{\text {high }}$ group whereas $32.33 \%$ of LumB tumor in MIRS ${ }^{\text {low }}$ subtype. However, we found that higher 
medRxiv preprint doi: https://doi.org/10.1101/2021.12.16.21267775; this version posted December 17, 2021. The copyright holder for this preprint (which was not certified by peer review) is the author/funder, who has granted medRxiv a license to display the preprint in

All rights reserved. No reuse allowed without permission.

321

322

proportion of Basal-like tumor was present in MIRS ${ }^{\text {low }}$ subtype. In Muenst et al.' study (30), they pointed out that the number of tumor-infiltrating lymphocytes was the highest in the basal-like subtype, which may support a high enrichment of basal-like tumor in MIRS $^{\text {low }}$ group. We also found that the normal-like had significantly lower MIRS than other molecular subtypes, in contrast to the LumB subtype had the highest MIRS (Figure 4J). In addition, a statistically significant difference was detected among these five intrinsic molecular subtypes by using Kruskal-Wallis method (Figure 4J). Similar results were found in METABRIC cohort (Supplementary Figure S11). These analyses indicate that MIRS group exhibited chaotic correlation with classic molecular subtypes, which could be attributed to the high tumorous heterogeneity in breast cancer.

\section{Identification of MIRS related biological characteristics in} prognosis of breast cancer

The above analyses implied high correlations between MIRS and tumor-infiltration microenvironment as well as tumor metastasis. We further explore the molecular mechanism of 12-gene panel underlying the prognosis of breast cancer. Initially, through literature, we found that the majority of those prognosis-related genes, except for APOA5, has been reported to be involved in the processes of tumorigenesis (Table S6). It is worth mentioning that APOA5, encoding an apolipoprotein, is associated with cardiovascular diseases $(31,32)$, but little work studies its roles in tumorigenesis and prognosis. To delineate its potential prognostic role in breast cancer, we divided APOA5 expression into four quartiles, then GSEA analysis between the highest and 
medRxiv preprint doi: https://doi.org/10.1101/2021.12.16.21267775; this version posted December 17, 2021. The copyright holder for this preprint (which was not certified by peer review) is the author/funder, who has granted medRxiv a license to display the preprint in

All rights reserved. No reuse allowed without permission.

lowers quartiles in TCGA-BRCA was conducted. Interestingly, many metastatic and immune-related pathways were observed to be enriched in the highest quartile, including EMT, TNF $\alpha$ signaling and Immune response regulating signaling pathways (Figure 5A and S12A). Subsequent survival analysis of pan-cancer based on TCGA cohorts was performed via Kaplan-Meier Plotter (https://kmplot.com/analysis/) (33), indicating that APOA5 may serve as prognostic indicator in many cancers (Figure S12B). The breast cancer patients with the highest APOA5 expression have a worse survival outcome (Figure S12B). Overall, our analysis hinted that APOA5 may exert its prognostic function to affect the immune activity in breast cancer, and it is likely to be a potential target for the future research of breast cancer therapy.

Genomic mutations are mostly involved in the survival prognosis of various cancers (34). Thus, we tested the associations between somatic mutations and MIRS in TCGA BRCA data. According to the analysis in the study of Chen et al (35), only the genes with somatic mutation frequencies more than $2.5 \%$ were included. By analyzing the mutation annotation of TCGA BRCA cohort, we selected the top 10 genes by mutation frequency. As provided in Figure 5B and C, MIRS ${ }^{\text {low }}$ group has increased frequency of mutation events than MIRS ${ }^{\text {high }}$ group. Rizvi et al (36) and Capalbo et al' studies (37) demonstrated that the patients with more mutations might have an increased number of neoantigens that enhance response to immunotherapy. This result might explain, in the present study, the reason that MIRS ${ }^{\text {low }}$ group has better prognostic outcomes than MIRS $^{\text {high }}$ group.

Recently, tumor mutation burden (TMB) is the paramount prognostic measure in 
medRxiv preprint doi: https://doi.org/10.1101/2021.12.16.21267775; this version posted December 17, 2021. The copyright holder for this preprint (which was not certified by peer review) is the author/funder, who has granted medRxiv a license to display the preprint in

All rights reserved. No reuse allowed without permission.

364

cancer survival (38). We further investigated the associations between MIRS and TMB.

As illustrated in Figure 5D, the patients in $\mathrm{MIRS}^{\text {low }}$ group exhibited markedly increased TMB when compared with those with MIRS ${ }^{\text {high }}$ group. Lee et al (39) and Karn et al's studies (40) showed that high TMB was associated with improved survival. Additionally, Chen et al (35) reported that the increased TMB was correlated to improved response to PD-1 blockades therapy. Correlation analysis between MIRS and TMB demonstrated that MIRS score was negligibly correlated with TMB (Spearman coefficient: $\mathrm{R}=-0.1, \mathrm{p}=0.0011$; Figure 5E). These findings indicate that MIRS may be related to immunotherapy response, and the patients with lower MIRS may have probably response in immunotherapy.

\section{The role of MIRS in the prediction of therapeutic}

\section{benefits}

To explore predictive ability of MIRS in immunotherapy for each patient, T cell inflamed score (TIS), IFN -gamma signature, antigen presenting machinery genes (APM) and Immunotherapyscore (IPS) (20, 41, 42), which are prevailing predictors of clinical response to immunotherapy across different tumor types were compared. Notably, the higher of TIS, IFN-gamma score, APM and IPS mean that patients receiving immunotherapy are more likely to response All patients in GSE20711 and GSE58812 with MIRS ${ }^{\text {low }}$ showed significantly increased predictor scores than those with MIRS ${ }^{\text {high }}$ (Figure 6A and S13A), which hints that MIRS ${ }^{\text {low }}$ group is more likely to have immunotherapy response. To further appraise the prognostic capability of 
medRxiv preprint doi: https://doi.org/10.1101/2021.12.16.21267775; this version posted December 17, 2021. The copyright holder for this preprint (which was not certified by peer review) is the author/funder, who has granted medRxiv a license to display the preprint in All rights reserved. No perpetuity.

reuse allowed without permission.

MIRS $^{\text {low }}$ group in immunotherapy, the differences in overall survival between MIRS ${ }^{\text {high }}$ and MIRS ${ }^{\text {low }}$ groups were compared using KM survival analysis in breast cancer testing cohort. Unfortunately, there are hitherto few public datasets of breast cancer patients receiving immunotherapy. Instead, the data of melanoma from Liu et al (43) and TCGA-SKCM dataset with patient receiving immunotherapy were used in present analysis. As a result, compared with PD-1 and TMB biomarkers upon receiving antiPD-1 treatment, MIRS showed robust AUCs (Figure 6B-D). Furthermore, the patients with MIRS ${ }^{\text {high }}$ have significantly shorter overall survival than their counterparts (Figure 6E and Figure S13B). MIRS significantly increases in patients with stable disease (SD) or progressive disease (PD) when compared with those with complete response (CR) or partial response (PR) (Figure 6F and Figure S13CB). Besides, the distributions of CR/PR and SD/PD across MIRS ${ }^{\text {high }}$ and MIRS $^{\text {low }}$ groups were also validated. We found that patients in MIRS ${ }^{\text {low }}$ group had better response to immunotherapy than those in MIRS $^{\text {high }}$ group (Figure 6G and Figure S13DC).

Moreover, to assess therapeutic value of MIRS in chemotherapy, we examined its predictive potential in GSE20685 with the breast cancer patients who receive adjuvant chemotherapy. The optimal cutoffs of MIRS were determined by the median cutoff, then the patients were stratified into MIRS ${ }^{\text {high }}$ and MIRS ${ }^{\text {low }}$ group. Survival analysis displays that the breast cancer patients with MIRS $^{\text {low }}$ had much better survival than those with MIRS ${ }^{\text {high }}$ in adjuvant chemotherapy cases (Figure 6H). We also investigated the prognosis of different MIRS subtypes with or without adjuvant chemotherapy. As illustrated in Figure 6I, we found that MIRS ${ }^{\text {high }}$ group had statistically significant 
medRxiv preprint doi: https://doi.org/10.1101/2021.12.16.21267775; this version posted December 17, 2021. The copyright holder for this preprint (which was not certified by peer review) is the author/funder, who has granted medRxiv a license to display the preprint in

All rights reserved. No reuse allowed without permission.

407 differences between the patients who were treated with adjuvant chemotherapy and 408 those without adjuvant chemotherapy. However, a consistent result was not observed 409 in those patients with MIRS ${ }^{\text {low }}$ (Figure 6J). These results indicated that adjuvant 410 chemotherapy might be more beneficial to $\mathrm{MIRS}^{\text {high }}$ group. Based on the gene sets of 411 different drug treatments retrieved from MSigDB database, GSEA predicted that 412 MIRS $^{\text {high }}$ was significantly correlated with drug sensitivity in TCGA cohort (Figure 6K).

413 Moreover, the $\mathrm{R}$ package pRRophetic was used to estimate the sensitivity of three 414 chemotherapeutic drugs, including cisplatin, tamoxifen and vincristine, which have 415 been commonly used in breast cancer treatment. The results showed that estimated IC50 416 values of cisplatin and vincristine significantly decrease in MIRS ${ }^{\text {high }}$ subtype (Figure 417 6L). We did not display IC50 boxplot of tamoxifen due to the R package 'pRRophetic' 418 does not contain resistant information regarding tamoxifen.

419 These results suggest that MIRS holds massive potential for predicting the response 420 to chemotherapy and immunotherapy in breast cancer patients. In brief, the patients 421 with MIRS ${ }^{\text {high }}$ may benefit from the chemotherapy, and patients with MIRS ${ }^{\text {low }}$ are likely 422 to be more sensitive to the immunotherapy.

424 Comparison of MIRS with the previously prognostic 425 models 
medRxiv preprint doi: https://doi.org/10.1101/2021.12.16.21267775; this version posted December 17, 2021. The copyright holder for this preprint (which was not certified by peer review) is the author/funder, who has granted medRxiv a license to display the preprint in

All rights reserved. No reuse allowed without permission.

428

429

430

431

432

433

434

435

436

437

438

439

440

441

442

443

444

445

446

447

model; Cui's score (44) constructed 8-gene signature based on traditional Lasso Cox model. We then comprehensively evaluate the prognostic power of our MIRS, mPS and Cui's score by Oprognostic Cox analyses based on a variety of public datasets. Our MIRS performed very well in different cohorts (Figure 7A). Although mPS showed to be more robust than MIRS in many datasets, some of the HRs in mPS panel were not significant $(\mathrm{P}$ value $>0.05)$ (Figure 7B). Cui's score performed the worst among these models (Figure 7C).

Furthermore, we scrutinized the predictive potential of these three models in the response to immunotherapy. The malignant melanoma cohort data (43) that receives anti-PD-1 therapy was used. The optimal cutoffs of Cui's score and mPS value were determined by the median. KM survival curves of MIRS show a significant difference in OS between MIRS ${ }^{\text {high }}$ and MIRS ${ }^{\text {low }}$ group (Figure 7E). On the contrary, the survival analysis of mPS and Cui's score revealed that patients with low mPS or Cui's score showed no statistically significant difference when compared with those with high mPS or Cui's score (Figure 7F-G). MIRS, mPS and Cui's score were also examined with time-dependent ROC analysis in the testing cohort for prediction in immunotherapeutic benefits. Notably, our MIRS exhibited much better predictive ability than mPS and Cui's score for OS at 1 year, 1.5 years, and 2 years, respectively (Figure 7D).

\section{Discussion}


medRxiv preprint doi: https://doi.org/10.1101/2021.12.16.21267775; this version posted December 17, 2021. The copyright holder for this preprint (which was not certified by peer review) is the author/funder, who has granted medRxiv a license to display the preprint in All rights reserved. No reuse allowed without permission.

449

450

451

452

453

454

455

456

457

458

459

460

461

462

463

464

465

466

467

468

469

470

sequencing data have significantly deepened the understanding of modern biology, enabling the scientists to thoroughly explore key characteristics in a variety of cancers.

Metastasis and tumor-immune infiltration are two of the major characteristics, and have been extensively proven to be associated with tumorigenesis, drug resistance and prognosis in breast cancer (43). Quite a few studies have disclosed the roles of metastasis and tumor-immune infiltration as prognostic factors in predicting the survival outcomes for breast cancer (45). Unfortunately, breast tumors are highly heterogeneous among individuals, and much current work has only considered organspecific metastasis or immune infiltration level and thus insufficient to achieve robust predictive power on prognosis. To address this issue, in this study we developed a comprehensive and efficient prognosis model, considering metastasis and immune infiltration levels together, to aid clinicians in providing precise treatment strategies.

Given the promising predictive value of MIRS, we systematically investigated the relationships between MIRS and clinical pathological characteristics. In different sequencing platform data, MIRS demonstrated as an independent prognosis factor compared with other conventional clinical features (Figure S14). As illustrated in Figure S17A, we observed differences between MIRS and Age, Gender and Metastasis variables. Subsequently, we used decision curve analysis (DCA) to decipher the effect in combining MIRS with clinical indicators. In the DCA analysis, the net benefit of clinical indicators combined with MIRS were better than of sole clinical indicator (Figure S17B). Additionally, we employed TCGA and GSE96058 datasets to investigate whether MIRS is suitable for all BRCA subtypes due to its complete subtype 
medRxiv preprint doi: https://doi.org/10.1101/2021.12.16.21267775; this version posted December 17, 2021. The copyright holder for this preprint (which was not certified by peer review) is the author/funder, who has granted medRxiv a license to display the preprint in

All rights reserved. No reuse allowed without permission.

471 information. However, we have not observed consistently predictive ability in both

472 datasets (Figure S18). This unsatisfied performance may come from the fact that we

473 built our MIRS model without tumor subtype information. Together, these results

474 demonstrate the validity and reliability of MIRS in clinical applications, but it no

475 suitable to all subtypes in breast cancer.

476 Next, we compared MIRS with the representative prognostic models, mPS and

477 Cui's score. Univariate cox regression analysis using nine public cohorts indicated that

478 MIRS and mPS performd well in most cohorts. These results indicated that,

479 constructing a prognostic system considering only metastatic features may be

480 insufficient. Compared with AI methods, traditional survival model showed weak

481 power. Nonetheless, mPS scoring system, based on an analogous AI approach, does not

482 work well in predicting immunotherapeutic. It might explain that the establishment of

483 mPS does not consider immunogenomic features, thus failing to achieve satisfactory

484 immunotherapeutic prediction.

485 Apart from being informative regarding prognosis, MIRS can also act as an

486 independent predictor to guide therapeutic strategies. Our analyses indicated that

487 MIRS $^{\text {high }}$ group had lower TIS, IPS, IFN-gamma score and APM score, implying

488 MIRS $^{\text {high }}$ group is more likely to escape from immunity in breast cancer. For further

489 validation, we tested if the OS between MIRS ${ }^{\text {high }}$ and MIRS ${ }^{\text {low }}$ groups was associated

490 with immunotherapy. We used two malignant melanoma cohorts with

491 immunotherapeutic information by conducting KM analysis. This survival analysis

492 showed that MIRS $^{\text {low }}$ group exhibited improved survival and better response to 
medRxiv preprint doi: https://doi.org/10.1101/2021.12.16.21267775; this version posted December 17, 2021. The copyright holder for this preprint (which was not certified by peer review) is the author/funder, who has granted medRxiv a license to display the preprint in

All rights reserved. No reuse allowed without permission.

493 immunotherapy than MIRS high. We speculate that the immunotherapy may achieve 494 beneficial treatment for MIRS ${ }^{\text {low }}$ patients.

495 Currently, chemotherapy is one of the main treatments for breast cancer. Hence, it 496 is necessary to identify patients who may potentially benefit from chemotherapy.

497 Through the analysis of breast cancer patients with chemotherapy clinical 498 information, we found that patients with MIRS ${ }^{\text {high }}$ respond better to chemotherapy than 499 patients with MIRS $^{\text {low }}$. Chemotherapy has been reported to be related to immune 500 infiltration (46). In the Ahn et al's study (47), they demonstrated that the high level of 501 the CD8+ TILs filtration is associated with chemotherapy resistance. This may be the 502 reason that high filtration MIRS ${ }^{\text {low }}$ subtype shows favorable chemotherapy. These 503 results emphasize the significance of $M I R S^{\text {high }}$ patients who could benefit from 504 chemotherapy.

As a gene prognostic signature particularly designed for breast cancer patients, MIRS is a novel and robust approach in risk stratification and personalized treatment.

507 However, there are still flaws in the current study. First, due to the remarkable intra508 tumor heterogeneity in breast cancer, we cannot cover all metastatic signatures despite 509 a large numbers of breast cancer patients used in this study. Second, only the median 510 cutoff of MIRS is used to classify the patients into high and low subtypes, the optimal 511 cutoff of MIRS would be needed to provide rational strategies. Lastly, all the 512 conclusions in this research are obtained from in silico studies, clinical experiments are required to confirm our findings. 
medRxiv preprint doi: https://doi.org/10.1101/2021.12.16.21267775; this version posted December 17, 2021. The copyright holder for this preprint (which was not certified by peer review) is the author/funder, who has granted medRxiv a license to display the preprint in

All rights reserved. No reuse allowed without permission.

515 to benefit from immunotherapy or chemotherapy. It would be of great significance to

516 validate the value of MIRS in prospective clinical trials.

\section{Contributors}

$518 \mathrm{CH}$ and XDZ conceived the presented idea. $\mathrm{CH}$, DLL and MD collected the public data,

$519 \mathrm{MD}$ and $\mathrm{CH}$ developed the methodology, MD and DLL analyzed the data under the 520 supervision of $\mathrm{CH}$. $\mathrm{CH}$ and $\mathrm{MD}$ took the lead in drafting the manuscript with input from

521 all authors. $\mathrm{CH}$, ELHL and XDZ revised the manuscript, PYZ and BQS interpreted 522 results from a clinical point of view. All authors read and approved the final manuscript.

\section{Declaration of competing interests}

524 The authors have declared that no competing interest exists

\section{Acknowledgements}

526 This work was supported by Dr. Neher's Biophysics Laboratory for Innovative Drug Discovery

527 (File no. 001/2020/ALC), by the Science and Technology Development Fund, Macau

528 Government (File no. 0020/2021/A), by the University of Macau (grant numbers: FHS-CRDA-

529 029-002-2017 and MYRG2018-00071-FHS), Zhongnanshan Medical Foundation of

530 Guangdong Province (grant number: ZNSA-2021016) and the Science and Technology 
medRxiv preprint doi: https://doi.org/10.1101/2021.12.16.21267775; this version posted December 17, 2021. The copyright holder for this preprint (which was not certified by peer review) is the author/funder, who has granted medRxiv a license to display the preprint in

All rights reserved. No reuse allowed without permission.

\section{Data sharing statement}

Data are available in a public, open access repository. All used data in the current study

534

535

536

537

538

539

540

541

542

543

544

545

546

547

548

549

550

551

552

553

554

555

556

557

558

559

560

561

562

563

564

565

566

are downloaded from Gene Expression Omnibus (GEO, https://www. ncbi. nlm. nih.

gov/geo/) and The Cancer Genome Atlas (TCGA) database (https:// cancergenome. nih. gov/).

\section{References}

1. Dumas A, Vaz Luis I, Bovagnet T, El Mouhebb M, Di Meglio A, Pinto S, et al. Impact of Breast Cancer Treatment on Employment: Results of a Multicenter Prospective Cohort Study (CANTO). J Clin Oncol. 2020;38(7):734-43.

2. Siegel RL, Miller KD, Jemal A. Cancer statistics, 2018. CA Cancer J Clin. 2018;68(1):7-30.

3. Afifi AM, Saad AM, Al-Husseini MJ, Elmehrath AO, Northfelt DW, Sonbol MB. Causes of death after breast cancer diagnosis: A US population-based analysis. Cancer. 2020;126(7):1559-67.

4. Gansler T, Ganz PA, Grant M, Greene FL, Johnstone P, Mahoney M, et al. Sixty years of CA: a cancer journal for clinicians. CA Cancer J Clin. 2010;60(6):345-50.

5. Landemaine T, Jackson A, Bellahcene A, Rucci N, Sin S, Abad BM, et al. A six-gene signature predicting breast cancer lung metastasis. Cancer research. 2008;68(15):6092-9.

6. Scott $E$. Androgen deprivation with or without radiation therapy for clinically node-positive prostate cancer. Lin CC, Gray PJ, Jemal A, Efstathiou JA, Surveillance and Health Services Research Program, Intramural Research, American Cancer Society, Atlanta, GA (CCL, AJ); Department of Radiation Oncology, Massachusetts General Hospital, Harvard Medical School, Boston, MA (PJG, JAE); e-mail: jefstathiou@partners.org. J Natl Cancer Inst. 2015 May 9;107(7). pii: djv119. [Print 2015 Jul]. doi: 10.1093/jnci/djv119. Urol Oncol. 2017;35(3):122-3.

7. Early Breast Cancer Trialists' Collaborative G. Effects of chemotherapy and hormonal therapy for early breast cancer on recurrence and 15-year survival: an overview of the randomised trials. Lancet. 2005;365(9472):1687-717.

8. Greenberg PA, Hortobagyi GN, Smith TL, Ziegler LD, Frye DK, Buzdar AU. Longterm follow-up of patients with complete remission following combination chemotherapy for metastatic breast cancer. J Clin Oncol. 1996;14(8):2197-205.

9. Cremasco V, Astarita JL, Grauel AL, Keerthivasan S, Maclsaac K, Woodruff MC, et al. FAP Delineates Heterogeneous and Functionally Divergent Stromal Cells in Immune-Excluded Breast Tumors. Cancer Immunol Res. 2018;6(12):1472-85. 
medRxiv preprint doi: https://doi.org/10.1101/2021.12.16.21267775; this version posted December 17, 2021. The copyright holder for this preprint (which was not certified by peer review) is the author/funder, who has granted medRxiv a license to display the preprint in

All rights reserved. No reuse allowed without permission.

567

568

569

570

571

572

573

574

575

576

577

578

579

580

581

582

583

584

585

586

587

588

589

590

591

592

593

594

595

596

597

598

599

600

601

602

603

604

605

606

607

608

609

610

10. Landemaine T, Jackson A, Bellahcene A, Rucci N, Sin S, Abad BM, et al. A six-gene signature predicting breast cancer lung metastasis. Cancer Res. 2008;68(15):6092-9. 11. Li J, Lenferink AE, Deng $Y$, Collins $C$, Cui $Q$, Purisima EO, et al. Identification of high-quality cancer prognostic markers and metastasis network modules. Nat Commun. 2010;1:34.

12. Xiao Z, Hu L, Yang L, Wang S, Gao Y, Zhu Q, et al. TGFbeta2 is a prognosticrelated biomarker and correlated with immune infiltrates in gastric cancer. J Cell Mol Med. 2020;24(13):7151-62.

13. Shen $Y$, Peng $X$, Shen $C$. Identification and validation of immune-related IncRNA prognostic signature for breast cancer. Genomics. 2020;112(3):2640-6.

14. Erdag G, Schaefer JT, Smolkin ME, Deacon DH, Shea SM, Dengel LT, et al. Immunotype and immunohistologic characteristics of tumor-infiltrating immune cells are associated with clinical outcome in metastatic melanoma. Cancer Res. 2012;72(5):1070-80.

15. Yang $L$, Wang $S$, Zhang $Q$, Pan $Y, L v Y$, Chen $X$, et al. Clinical significance of the immune microenvironment in ovarian cancer patients. Mol Omics. 2018;14(5):34151.

16. Barnes TA, Amir E. HYPE or HOPE: the prognostic value of infiltrating immune cells in cancer. British journal of cancer. 2017;117(4):451-60.

17. Pérez-Romero K, Rodríguez RM, Amedei A, Barceló-Coblijn G, Lopez DH. Immune Landscape in Tumor Microenvironment: Implications for Biomarker Development and Immunotherapy. International Journal of Molecular Sciences. 2020;21(15):5521. 18. Liu R, Hu R, Zeng $Y$, Zhang $W$, Zhou H-H. Tumour immune cell infiltration and survival after platinum-based chemotherapy in high-grade serous ovarian cancer subtypes: A gene expression-based computational study. EBioMedicine.

2020;51:102602.

19. Davis S, Meltzer PS. GEOquery: a bridge between the Gene Expression Omnibus (GEO) and BioConductor. Bioinformatics. 2007;23(14):1846-7.

20. Charoentong P, Finotello F, Angelova M, Mayer C, Efremova M, Rieder D, et al.

Pan-cancer immunogenomic analyses reveal genotype-immunophenotype relationships and predictors of response to checkpoint blockade. Cell reports. 2017;18(1):248-62.

21. Charoentong $P$, Finotello $F$, Angelova $M$, Mayer $C$, Efremova $M$, Rieder $D$, et al. Pan-cancer Immunogenomic Analyses Reveal Genotype-Immunophenotype Relationships and Predictors of Response to Checkpoint Blockade. Cell Rep. 2017;18(1):248-62.

22. Bhattacharya S, Dunn P, Thomas CG, Smith B, Schaefer H, Chen J, et al. ImmPort, toward repurposing of open access immunological assay data for translational and clinical research. Sci Data. 2018;5:180015.

23. Hänzelmann S, Castelo R, Guinney J. GSVA: gene set variation analysis for microarray and RNA-seq data. BMC bioinformatics. 2013;14(1):7.

24. Gentleman R, Carey VJ. Unsupervised machine learning. Bioconductor case studies: Springer; 2008. p. 137-57.

25. Benjamini $Y$, Hochberg Y. Controlling the false discovery rate: a practical and 
medRxiv preprint doi: https://doi.org/10.1101/2021.12.16.21267775; this version posted December 17, 2021. The copyright holder for this preprint (which was not certified by peer review) is the author/funder, who has granted medRxiv a license to display the preprint in

powerful approach to multiple testing. Journal of the Royal statistical society: series B (Methodological). 1995;57(1):289-300.

26. Shimizu H, Nakayama KI. A 23 gene-based molecular prognostic score precisely predicts overall survival of breast cancer patients. EBioMedicine. 2019;46:150-9. 27. Agarap AF. Deep learning using rectified linear units (relu). arXiv preprint arXiv:180308375. 2018.

28. Yoshihara K, Shahmoradgoli M, Martínez E, Vegesna R, Kim H, Torres-Garcia W, et al. Inferring tumour purity and stromal and immune cell admixture from expression data. Nature communications. 2013;4(1):1-11.

29. Wakita K, Kohno N, Sakoda Y, Ishikawa Y, Sakaue M. Decreased expression of the DCC gene in human breast carcinoma. Surgery today. 1996;26(11):900-3. 30. Muenst S, Soysal S, Gao F, Obermann E, Oertli D, Gillanders W. The presence of programmed death 1 (PD-1)-positive tumor-infiltrating lymphocytes is associated with poor prognosis in human breast cancer. Breast cancer research and treatment. 2013;139(3):667-76.

31. Dallongeville J, Cottel D, Montaye M, Codron V, Amouyel P, Helbecque N. Impact of APOA5/A4/C3 genetic polymorphisms on lipid variables and cardiovascular disease risk in French men. International journal of cardiology. 2006;106(2):152-6. 32. Lin Y-C, Nunez V, Johns R, Shiao SPK. APOA5 gene polymorphisms and cardiovascular diseases: metaprediction in global populations. Nursing research. 2017;66(2):164-74.

33. Nagy Á, Munkácsy G, Győrffy B. Pancancer survival analysis of cancer hallmark genes. Scientific reports. 2021;11(1):1-10.

34. Gotea V, Gartner JJ, Qutob N, Elnitski L, Samuels Y. The functional relevance of somatic synonymous mutations in melanoma and other cancers. Pigment cell \& melanoma research. 2015;28(6):673-84.

35. Chen Z, Yuan Y, Chen X, Chen J, Lin S, Li X, et al. Systematic comparison of somatic variant calling performance among different sequencing depth and mutation frequency. Scientific reports. 2020;10(1):1-9.

36. Rizvi NA, Hellmann MD, Snyder A, Kvistborg P, Makarov V, Havel JJ, et al. Mutational landscape determines sensitivity to PD-1 blockade in non-small cell lung cancer. Science. 2015;348(6230):124-8.

37. Capalbo C, Scafetta G, Filetti M, Marchetti P, Bartolazzi A. Predictive biomarkers for checkpoint inhibitor-based immunotherapy: the galectin-3 signature in NSCLCs. International journal of molecular sciences. 2019;20(7):1607.

38. Riviere P, Goodman AM, Okamura R, Barkauskas DA, Whitchurch TJ, Lee S, et al. High tumor mutational burden correlates with longer survival in immunotherapynaïve patients with diverse cancers. Molecular Cancer Therapeutics. 2020;19(10):2139-45.

39. Lee D-W, Han S-W, Bae JM, Jang H, Han H, Kim H, et al. Tumor mutation burden and prognosis in patients with colorectal cancer treated with adjuvant fluoropyrimidine and oxaliplatin. Clinical Cancer Research. 2019;25(20):6141-7. 40. Karn T, Denkert C, Weber K, Holtrich U, Hanusch C, Sinn B, et al. Tumor mutational burden and immune infiltration as independent predictors of response to 
medRxiv preprint doi: https://doi.org/10.1101/2021.12.16.21267775; this version posted December 17, 2021. The copyright holder for this preprint (which was not certified by peer review) is the author/funder, who has granted medRxiv a license to display the preprint in

All rights reserved. No reuse allowed without permission.

655

656

657

658

659

660

661

662

663

664

665

666

667

668

669

670

671

672

673

674

675

676

677

678

679

680

681

682

neoadjuvant immune checkpoint inhibition in early TNBC in GeparNuevo. Annals of Oncology. 2020;31(9):1216-22.

41. Ayers M, Lunceford J, Nebozhyn M, Murphy E, Loboda A, Kaufman DR, et al. IFN$\checkmark$-related mRNA profile predicts clinical response to PD-1 blockade. The Journal of clinical investigation. 2017;127(8):2930-40.

42. Kamoun A, de Reyniès A, Allory $Y$, Sjödahl G, Robertson AG, Seiler R, et al. A consensus molecular classification of muscle-invasive bladder cancer. European urology. 2020;77(4):420-33.

43. Liu $D$, Schilling $B$, Liu $D$, Sucker $A$, Livingstone $E$, Jerby-Amon $L$, et al. Integrative molecular and clinical modeling of clinical outcomes to PD1 blockade in patients with metastatic melanoma. Nature medicine. 2019;25(12):1916-27.

44. Cui $Q$, Tang J, Zhang D, Kong D, Liao X, Ren J, et al. A prognostic eight - gene expression signature for patients with breast cancer receiving adjuvant chemotherapy. Journal of cellular biochemistry. 2020;121(8-9):3923-34.

45. Wang S, Zhang Q, Yu C, Cao Y, Zuo Y, Yang L. Immune cell infiltration-based signature for prognosis and immunogenomic analysis in breast cancer. Briefings in bioinformatics. 2020.

46. Mesnage S, Auguste A, Genestie C, Dunant A, Pain E, Drusch F, et al. Neoadjuvant chemotherapy (NACT) increases immune infiltration and programmed death-ligand 1 (PD-L1) expression in epithelial ovarian cancer (EOC). Annals of Oncology. 2017;28(3):651-7.

47. Ahn S, Chung YR, Seo AN, Kim M, Woo JW, Park SY. Changes and prognostic values of tumor-infiltrating lymphocyte subsets after primary systemic therapy in breast cancer. PloS one. 2020;15(5):e0233037.

\section{Tables}

Table 1. The 12 prognostic genes for calculating the risk score in TCGA data

\begin{tabular}{llccc}
\hline Gene ID & Category & $\begin{array}{c}\text { Gene expression } \\
\text { (high) }\end{array}$ & $\begin{array}{c}\text { Gene expression } \\
\text { (low) }\end{array}$ & Weight \\
\hline APOA5 & Dangerous & 1 & 0 & 0.4703 \\
FAM9C & Dangerous & 1 & 0 & 0.5585 \\
IVL & Dangerous & 1 & 0 & 0.4467 \\
PAGE5 & Dangerous & 1 & 0 & 0.5637 \\
CACNA1E & Protective & 0 & 1 & 0.3596 \\
CCL25 & Protective & 0 & 1 & 0.5013 \\
CD1A & Protective & 0 & 1 & 0.1782 \\
CD1B & Protective & 0 & 1 & 0.7733 \\
GPR55 & Protective & 0 & 1 & 0.6999
\end{tabular}




\section{Figure Legends}

$\begin{array}{lllll}\text { LAX1 } & \text { Protective } & 0 & 1 & 0.6383 \\ \text { TNFRSF8 } & \text { Protective } & 0 & 1 & 0.6234 \\ \text { WNT10A } & \text { Protective } & 0 & 1 & 0.4189\end{array}$

Figure 1. Systematic bioinformatic analysis pipeline.

Figure 2. Exploration of the immune cell infiltration grouping, and 52 candidate genes were expressed in BRCA samples from the TCGA, GSE10893, and GSE3521 datasets.

(A) Heatmap for the high and low immune-cell infiltration grouping from the TCGA cohort.

(B) Boxplots for the expression levels of the CD family gene between high and low infiltration groups.

(C) Comparison of Stromal score, Immunity score, ESTIMATE score and Tumor purity between the high and low immune infiltration groups.

(D) Boxplots illustrate the 22 immune cell proportion s between high and low immune infiltration groups.

(E) Venn plot of the differentially expressed genes from the TCGA data and GEO datasets.

(F) Heatmap of the 52 candidate gene expression values between high and low immune infiltration groups from the TCGA dataset. Cluste1 represents the low immune infiltration level group, cluster 2 represents the high immune infiltration level group.

(G) Volcano plot of the 52 candidate genes between the primary and metastasis tumor groups both from the GSE3521 and GSE10893. The blue dots show the DE genes are down regulated in the metastasis group. The red dots display the DE genes are up regulated in the metastasis group. The pvalues were calculated using Wilcox rank sum test.

\section{Figure 3. Construction and validation of the MIRS in the training and testing} cohorts.

A. The square root of the variance inflation factor value for each candidate gene in the training data.

B. Correlations between the candidate genes in the training TCGA data. Different correlations between two genes are represented by different colors.

C. ROC curve for the patient's overall survival prediction in the training TCGA data.

D. Kaplan-Meier curves of overall survival according to the MIRS subtypes in the training TCGA data.

E. ROC curve for the patient's overall survival prediction in GSE96058.

F. Kaplan-Meier curves of overall survival according to the MIRS subtypes in GSE96058.

G. ROC curve for the patient's overall survival prediction in GSE86166.

H. Kaplan-Meier curves of overall survival according to the MIRS subtypes in GSE86166. 
medRxiv preprint doi: https://doi.org/10.1101/2021.12.16.21267775; this version posted December 17, 2021. The copyright holder for this preprint (which was not certified by peer review) is the author/funder, who has granted medRxiv a license to display the preprint in

Figure 4. Correlation of MIRS with the metastatic and immunogenomic landscape between the high and low MIRS subtypes.

A. Comparison of the Stromal score, ESTIMATE score, Immune score, and Tumor purity between high and low MIRS subtypes in GSE86166. The p-values were calculated using Wilcoxon rank sum test. ${ }^{*} \mathrm{p}<0.05 ; * * \mathrm{p}<0.01 ; * * * \mathrm{p}<0.0001$.

B. Function enrichment bar plot for the genes in GSE86166 which were highly correlated (Spearman correlation coefficient $\geq 0.04$ ) with 12 prognostic genes in GSE86166.

C. Boxplots of the ssGSEA score for 17 immune-related biological functions and pathways between two MIRS subtypes in the GSE86166. The p-values were calculated using Wilcoxon rank sum test. ${ }^{*} \mathrm{p}<0.05 ;{ }^{* *} \mathrm{p}<0.01 ; * * * \mathrm{p}<0.0001$.

D. The spearman correlation between the gene expression levels of PD-1, PD-L1 and CTLA4 and MIRS score in the GSE86166 data, respectively.

E. The boxplots of PD-1, PD-L1 and CTLA4 for two MIRS subtypes in the GSE86166 data. The p-values were calculated using Wilcoxon rank sum test. ${ }^{*} \mathrm{p}<0.05 ;{ }^{* *} \mathrm{p}<0.01 ;{ }^{* * *} \mathrm{p}<0.0001$.

F. The boxplots of DCC, MMP9 and ETS1 for two MIRS subtypes in GSE86166 dataset. The pvalues were calculated using Wilcoxon rank sum test. ${ }^{*} \mathrm{p}<0.05 ;{ }^{* *} \mathrm{p}<0.01 ;{ }^{* * *} \mathrm{p}<0.0001$.

G. Boxplots of the ssGSEA score for 23 metastatic biological functions and pathways between two MIRS subtypes in the GSE86166. The p-values were calculated using Wilcoxon rank sum test. ${ }^{*} \mathrm{p}<0.05 ; * * \mathrm{p}<0.01 ; * * * \mathrm{p}<0.0001$.

H. The spearman correlation between the gene expression levels of DCC, MMP9 and ETS1 and MIRS score in the GSE86166, respectively.

I. Sankey diagram for the MIRS values with different intrinsic molecular subtypes in TCGA patients.

J. Violin plots for the distribution of MIRS values in different intrinsic molecular subtypes at TCGA BRCA cohort. The p-values were calculated using Kruskal-Wallis test. ${ }^{*} \mathrm{p}<0.05$; $* * \mathrm{p}<0.01 ; * * * \mathrm{p}<0.0001$

\section{Figure 5. Identification of MIRS-related biological characteristics in prognosis of} breast cancer.

A. GSEA enrichment plots in TCGA.

B. The Oncoplot of top 10 genes with the highest mutation frequency in high MIRS group (TCGA data).

C. The Oncoplot of top 10 genes with the highest mutation frequency in low MIRS group (TCGA data).

D. Boxplots of the MIRS score between the high and low TMB subtypes in TCGA data. The pvalues were calculated using Wilcoxon rank sum test.

E. The spearman correlation between the MIRS score and TMB values in TCGA data.

A. The boxplot of TIS, IPS, APM score and IFN gamma score between the high and low MIRS in GSE20711.

B. ROC curves between the expression level of PD-1, TMB and MIRS of anti-PD1 immunotherapy response prediction in Liu et al data.

C. Time-dependent ROC curves of MIRS for anti-PD1 immunotherapy response prediction in the 
medRxiv preprint doi: https://doi.org/10.1101/2021.12.16.21267775; this version posted December 17, 2021. The copyright holder for this preprint (which was not certified by peer review) is the author/funder, who has granted medRxiv a license to display the preprint in

All rights reserved. No reuse allowed without permission.

Liu et al data.

D. Time-dependent ROC curves of the expression level for anti-PD1 immunotherapy response prediction in Liu et al data.

E. Kaplan-Meier curves of overall survival according to MIRS subtypes in the Liu et al data.

F. Violin plot illustrating the distribution of MIRS for patients with different immunotherapy response in Liu et al data.

G. Bar graph showing the number of clinical responses to anti-PD-1 immunotherapy in the high and low MIRS subtypes in Liu et al data.

H. Kaplan-Meier curves of overall survival according to MIRS subtypes with chemotherapy in GSE20685.

I. Kaplan-Meier curves of overall survival according to the high MIRS subtype with or without chemotherapy in GSE20685.

J. Kaplan-Meier curves of overall survival according to the low MIRS subtype with or without chemotherapy in GSE20685.

K. GSEA predict that high MIRS group is negatively correlated with drug resistance in TCGA cohort.

L. Chemotherapeutic sensitivity of two drugs (Cisplatin, Vincristine) were estimated and compared in TCGA cohort.

\section{Figure 7. Compare MIRS with previous prognosis signatures.}

A. A meta-analysis was performed using the prognosis results of MIRS in nine public datasets.

B. A meta-analysis was performed using the prognosis results of mPS in nine public datasets.

C. A meta-analysis was performed using the prognosis results of Cui's score in nine public datasets.

D. Time-dependent ROC curves of anti-PD-1 immunotherapy on the 1-,1.5-,2-year survival rates for Liu et al data.

E. Kaplan-Meier curves of overall survival according to MIRS subtype with immunotherapy in Liu et al data.

F. Kaplan-Meier curves of overall survival according to mPS subtype with immunotherapy in Liu et al data.

G. Kaplan-Meier curves of overall survival according to Cui's score subtype with immunotherapy in Liu et al data. 

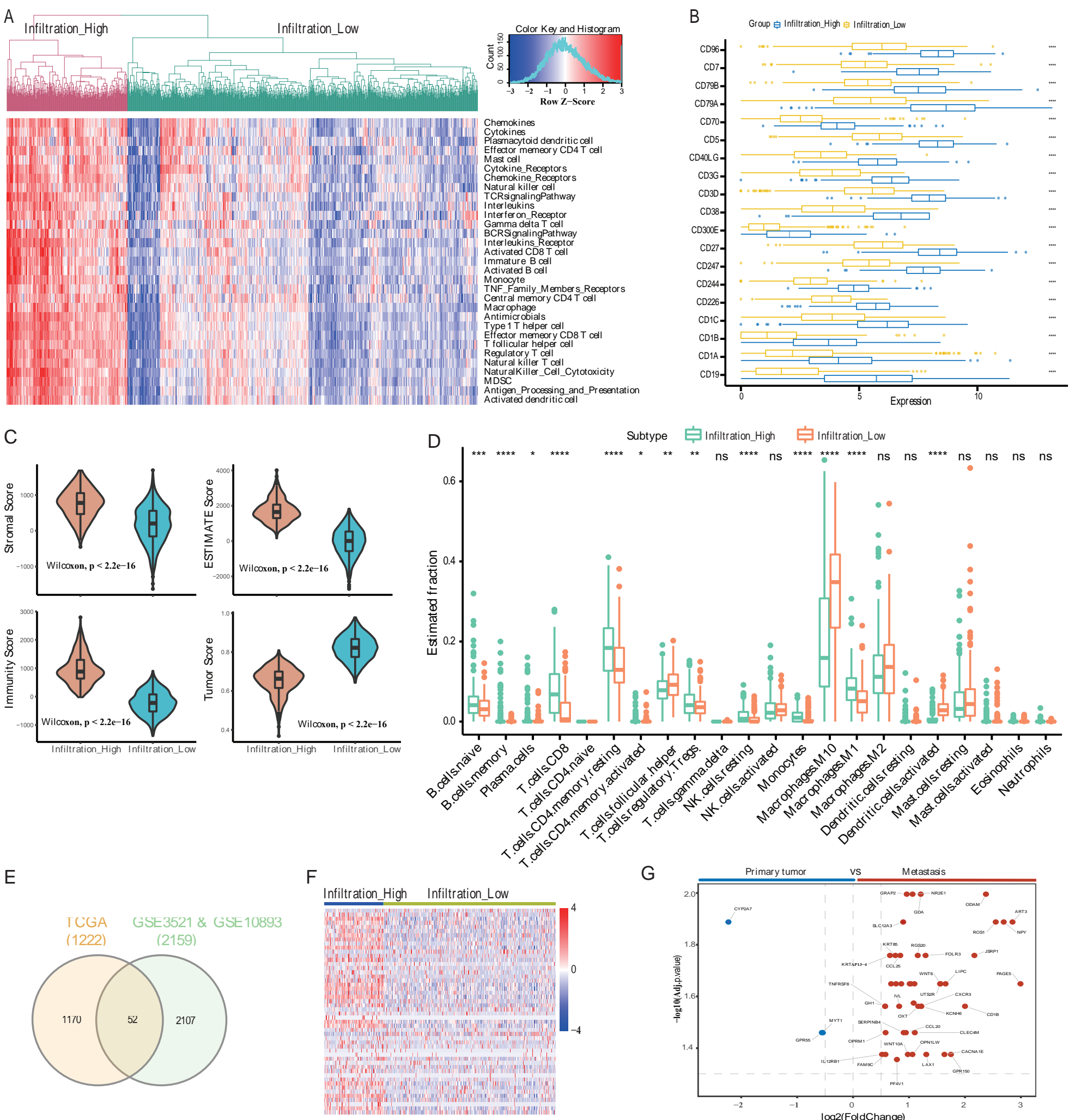
A

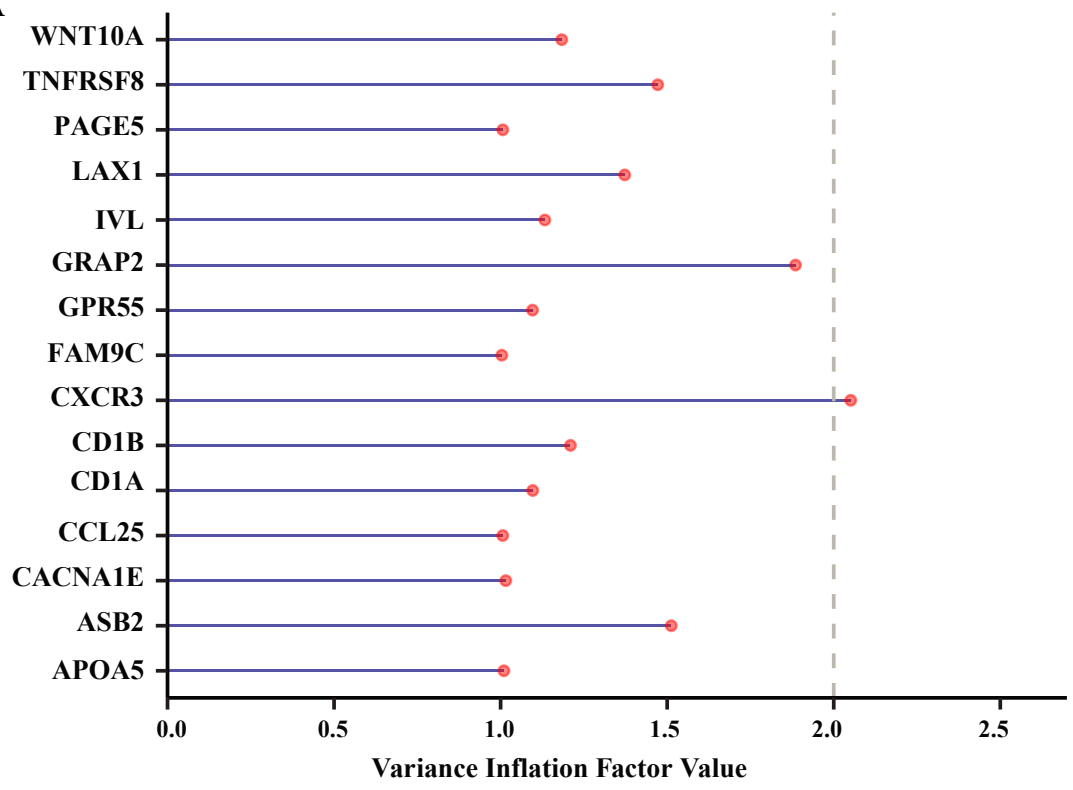

B

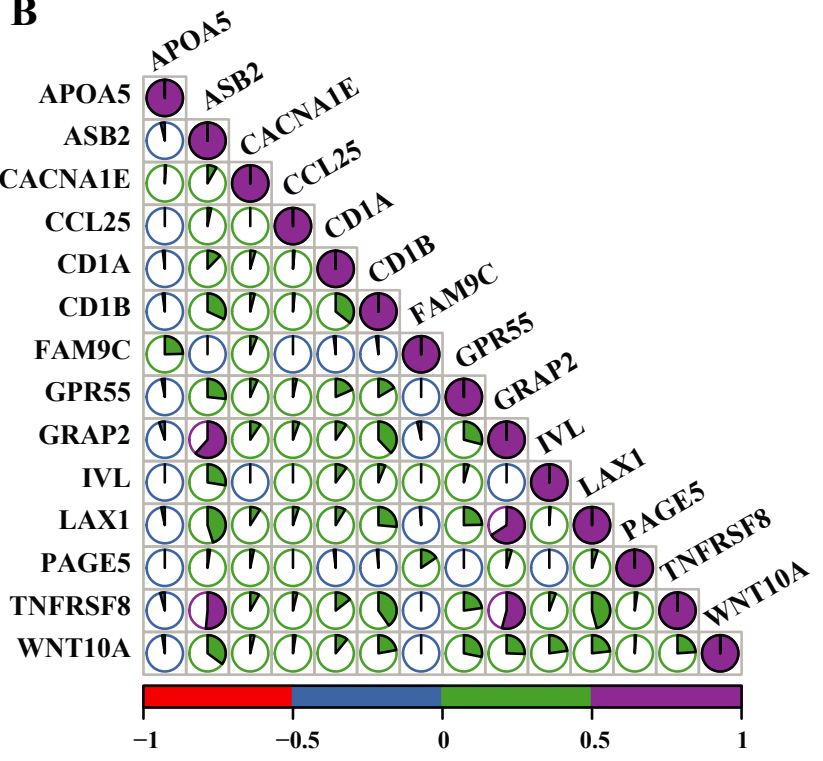

C

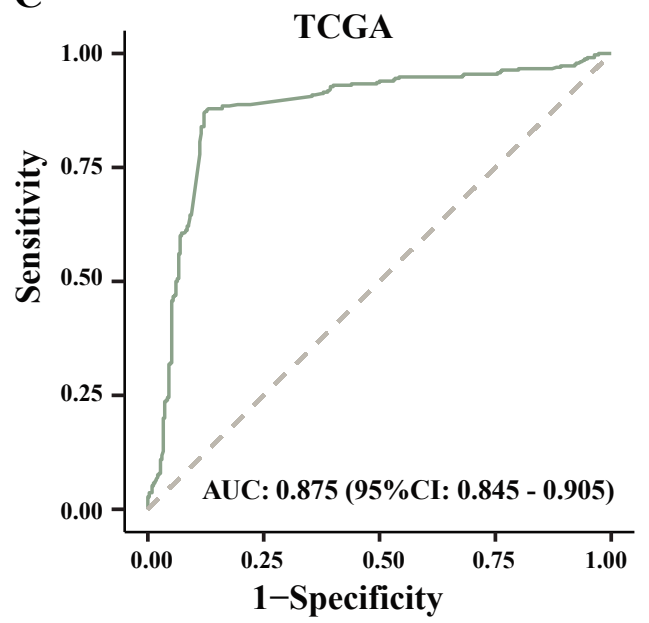

F

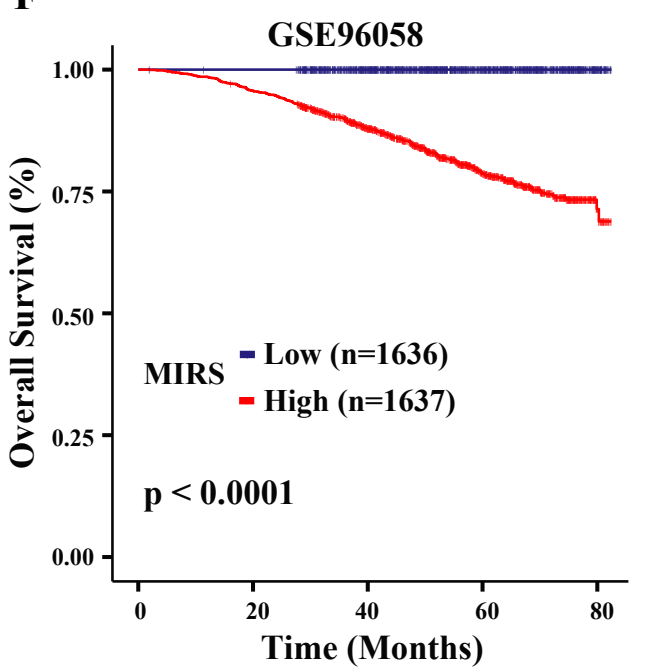

D

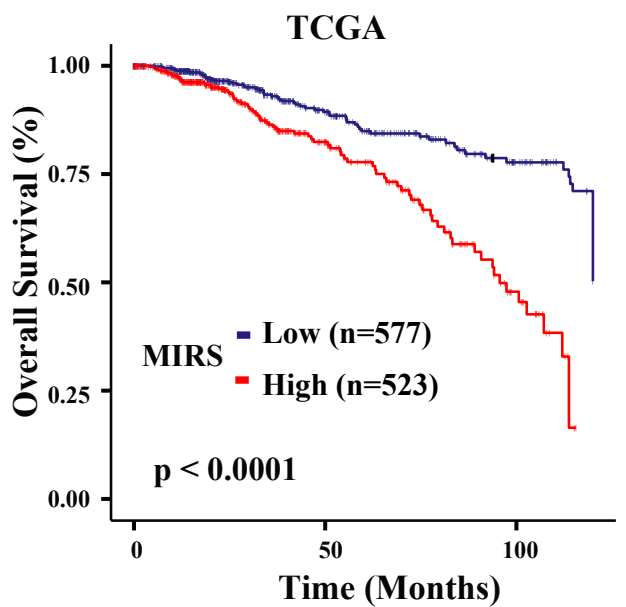

G

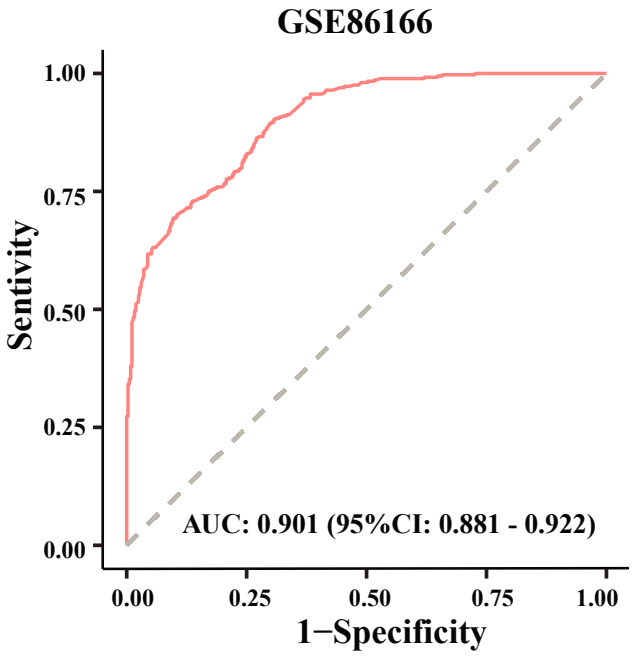

E

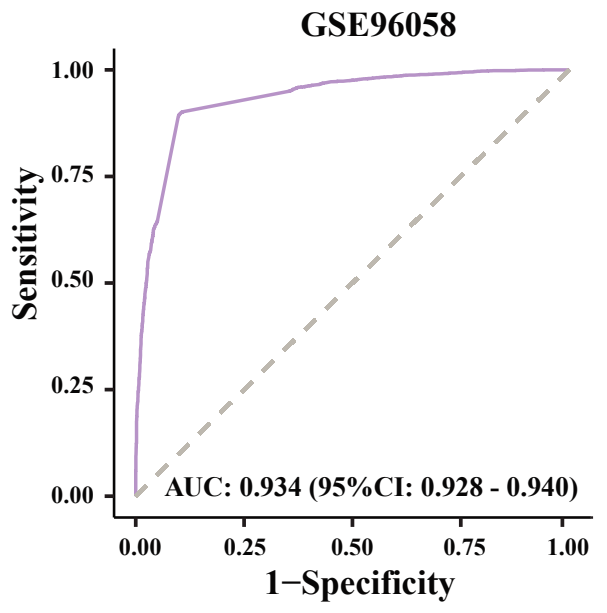

H

GSE86166

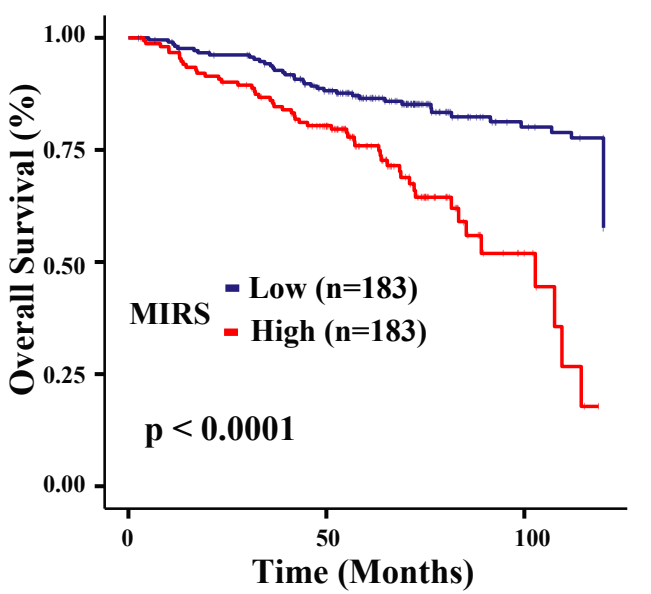



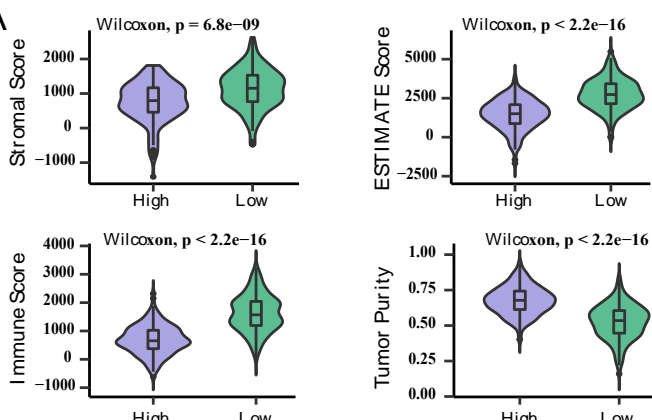

B

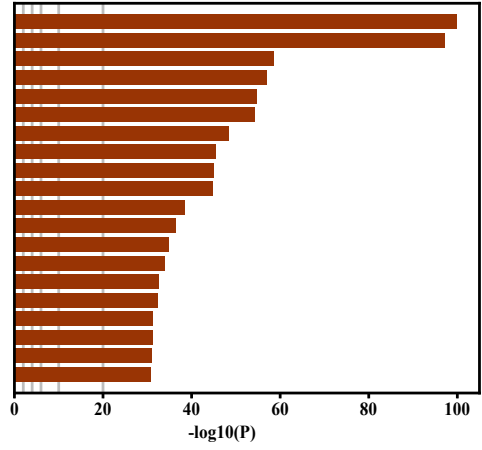

O:0042110: $\mathrm{T}$ cell activation

GO:0002683: negative regulation of immune system process -HSA-1280218: Adaptive Immune System 0:0001819: positive regulation of cytokine production 60.0002697: regulation of immune effector process 0:0002366: leukocyte activation involved in imm une response 0:0046631: alpha-beta Tration

GO:0042113: B cell activation

0:0031349: positive regulation of defense respons 04060: Cytokine-cytokine receptor interaction

ietic cell lineage

GO:0002285: lymphocyte activation involved in immune response G:0009617: response to bacterium

554: PID IL12 2PATHWAY

GO:0072676: lymphocyte migration

GO:0034341: response to interferon-gamm GO:0050727: regulation of inflammatory response
C

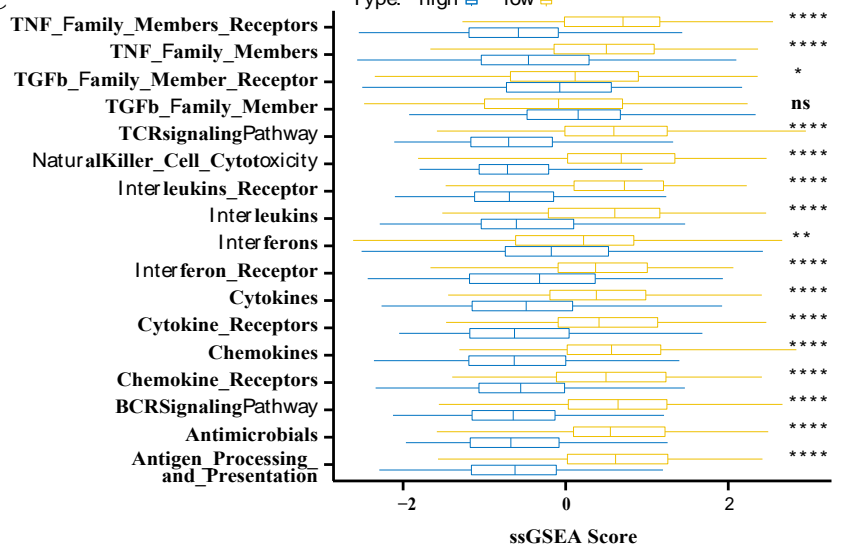

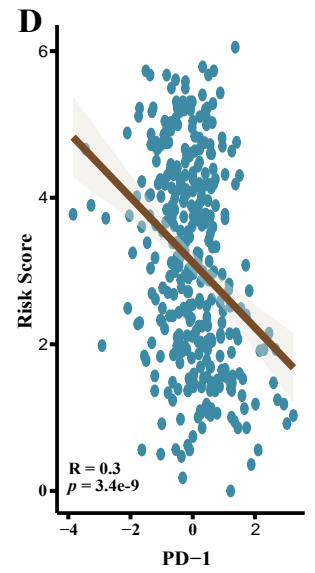

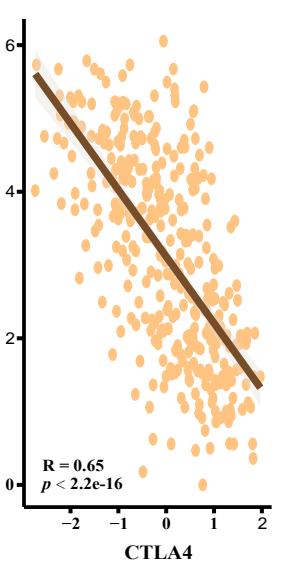

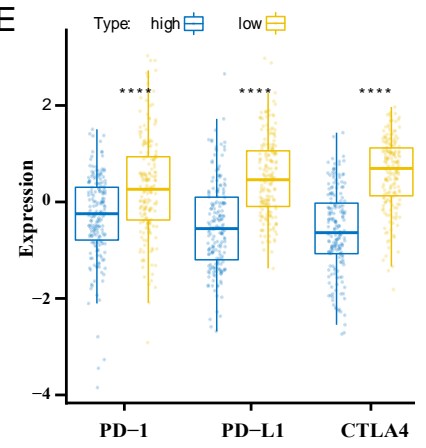

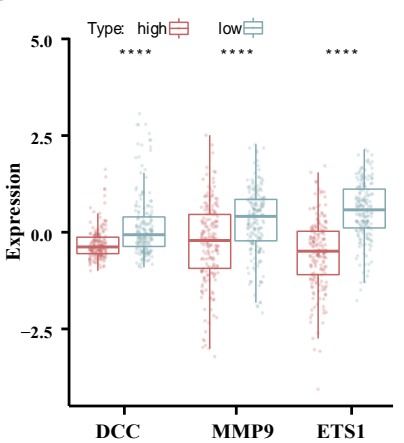

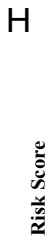

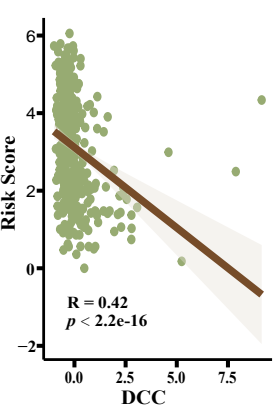

WP_OXIDATION_BY_CYTOCHR $\square$ ME_P450 REACTOME_BIOLOGICAL_OXIDATIONS REACTOME_RA_BIOSYNTHESIS_ $\square$ ATHWAY YAMASHITA_LIVER_CANCER_STEM_CELL_DN REACTOME_TRANSPORT_OF_VITAMINS NUCLEOSIDES_AND_RELATED_M LECULES WEBER_METHYLATED_LCP_IN_SPERM_UP REACTOME_CYTOCHROME_P450 ARRANGED_BY_SUBSTR $\square$ TE_TYPE WP_UREA_CYCLE_AND_METABOLISM_OF_AMIN $\square$ GROUPS WP_CODEINE_AND_MORPHINE_METABOLISM KEGG_PENTOSE_AND_GLUCURONATE_INTERCO $\square \square \square \square \square-$ LEE_LIVER_CANCER_ACOX1_DN MINGUEZ_LIVER_CANCER_VASCULAR_INV $\square$ SION_DN KEGG_PRIMARY_BILE_ACID_BIOSY $\square \square \square \square \square \square \square-$ REACTOME_REGULATION_OF_TLR_BY_ENDOGENOUS_LIGAND WP_GLUCURONIDATION WP_ESTROGEN_METABOLISM NIKOLSKY_BREAST_CANCER_17Q11_Q21_A $\square$ PLICON RICKMAN_HEAD_AND_NECK_CANCER_E WP_FLUOROPYRIMIDINE_ACTIVITY REACTOME DEFECTS OF CONTACT ACTIVATION SYSTEM CAS_AND KALLIKREIN_KININ SY TEM_KKS KEGG_STEROID_HORMONE_BIOSYNTHESIS VARELA_ZMPSTE24_TARGETS_DN WAGSCHAL_EHMT2_TARGETS_UP -

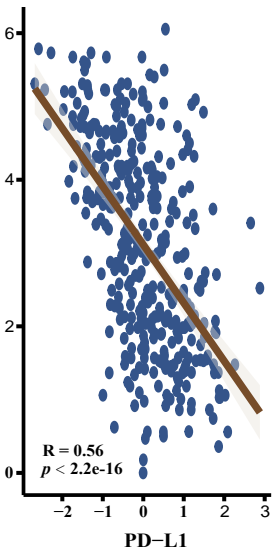

PD-L1

미: 血它 田它

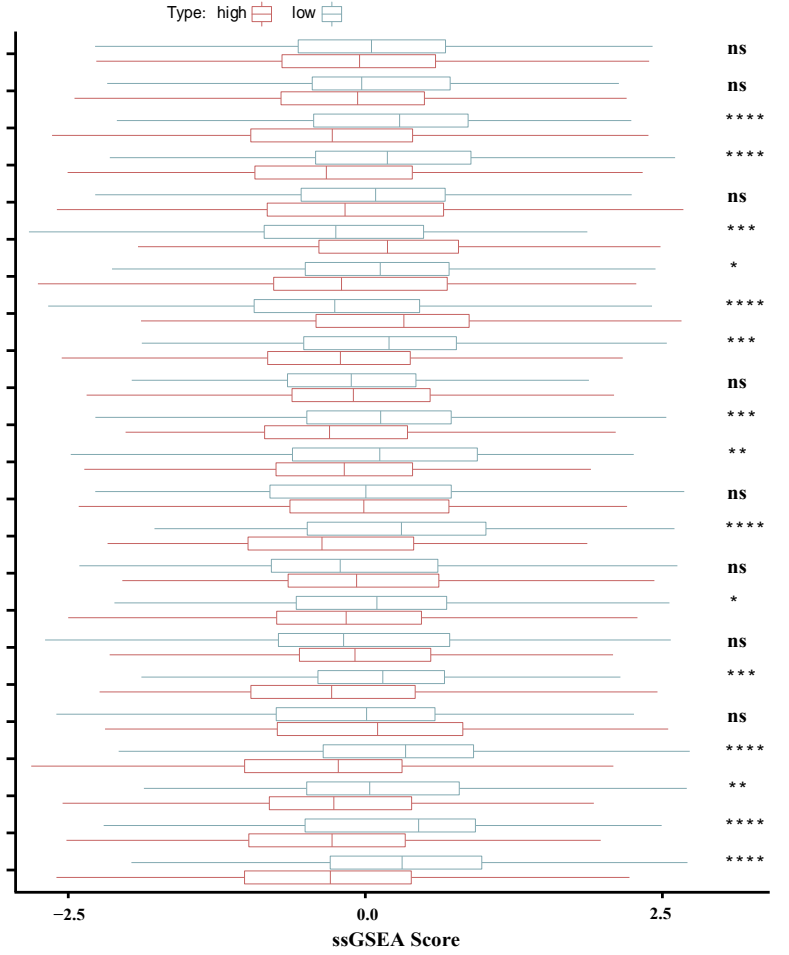


medRxiv preprint doi: https://doi.org/10.1101/2021.12.16.21267775; this version posted December 17, 2021. The copyright holder for this preprint (which was not certified by peer review) is the author/funder, who has granted medRxiv a license to display the preprint in perpetuity.

All rights reserved. No reuse allowed without permission.

A

EPITHELIAL_MESENCHYMAL_TRANSITION

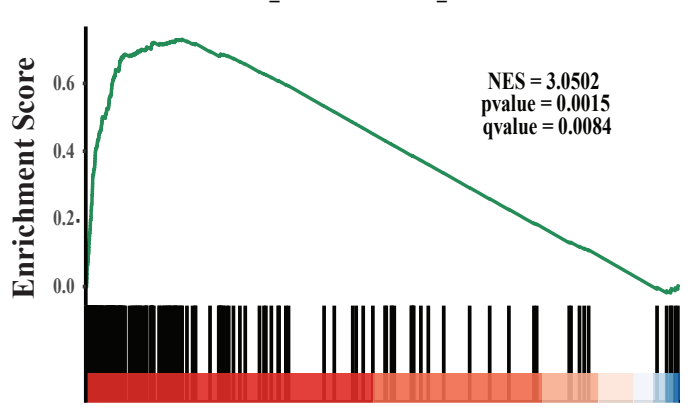

TNFA_SIGNALING_VIA_NFKB

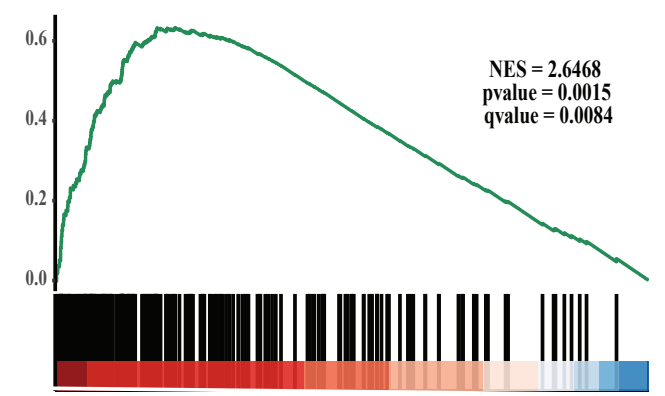

IMMUNE_RESPONSE_REGULATING_SIGNALING_PATHWAY

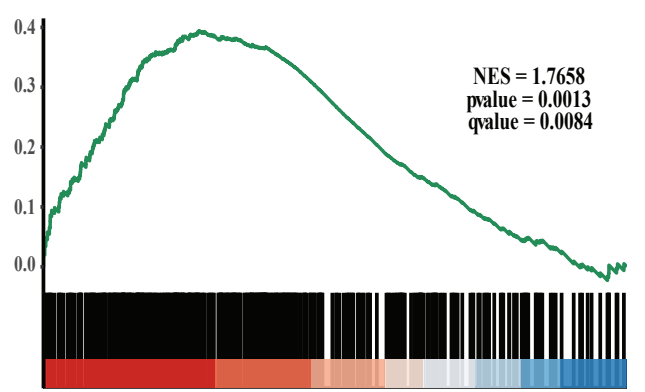

B

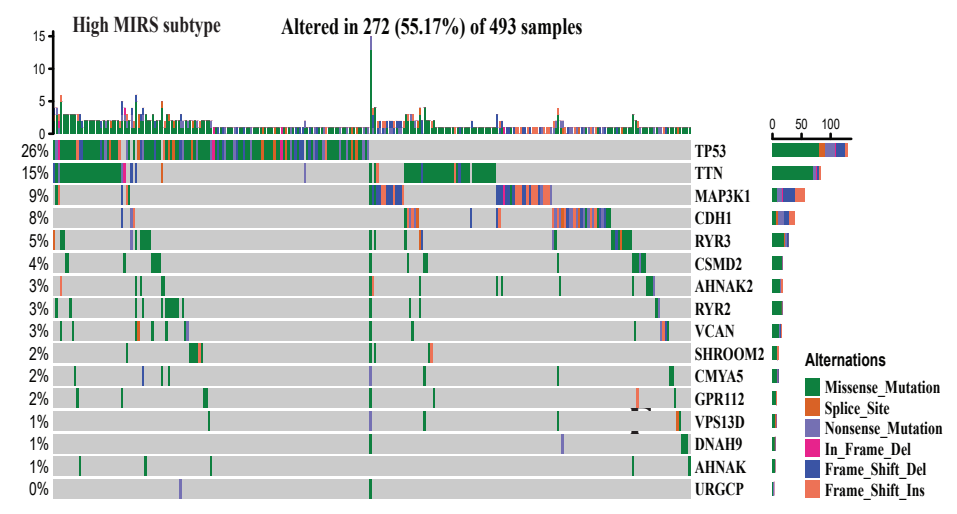

D

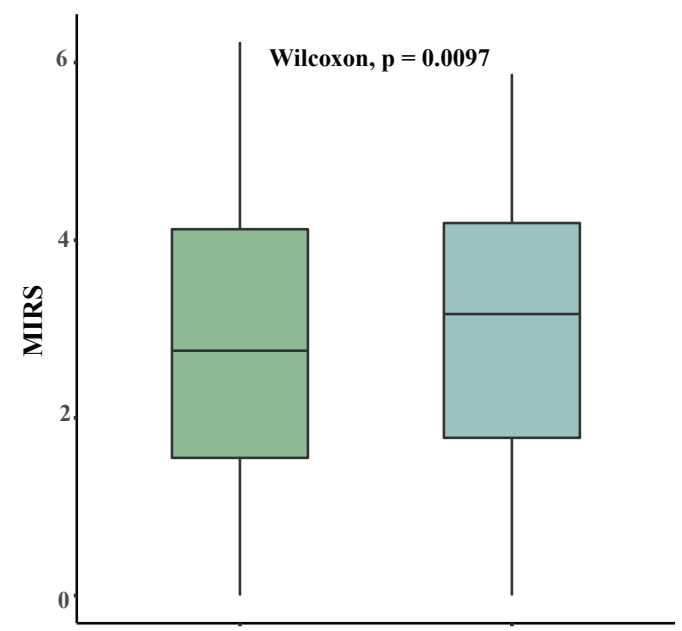

High TMB

Low TMB
C

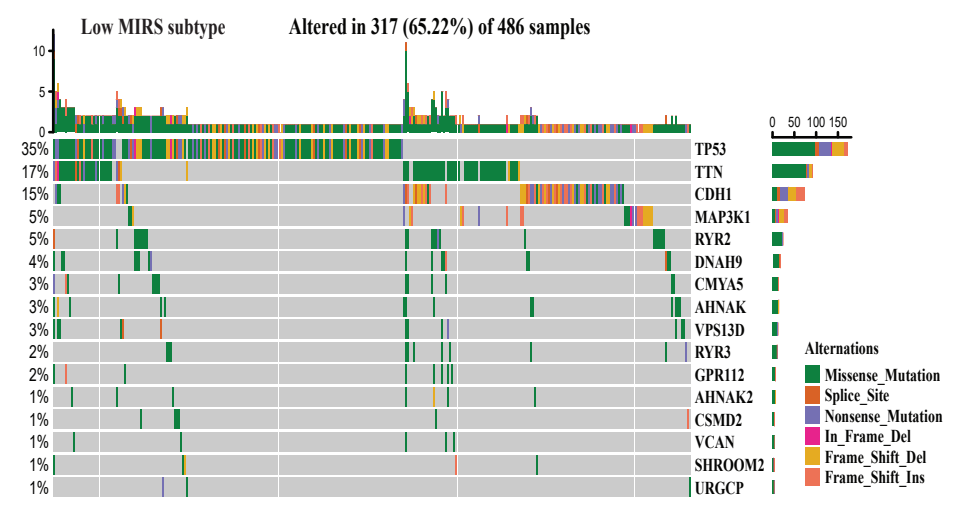

$\mathbf{E}$

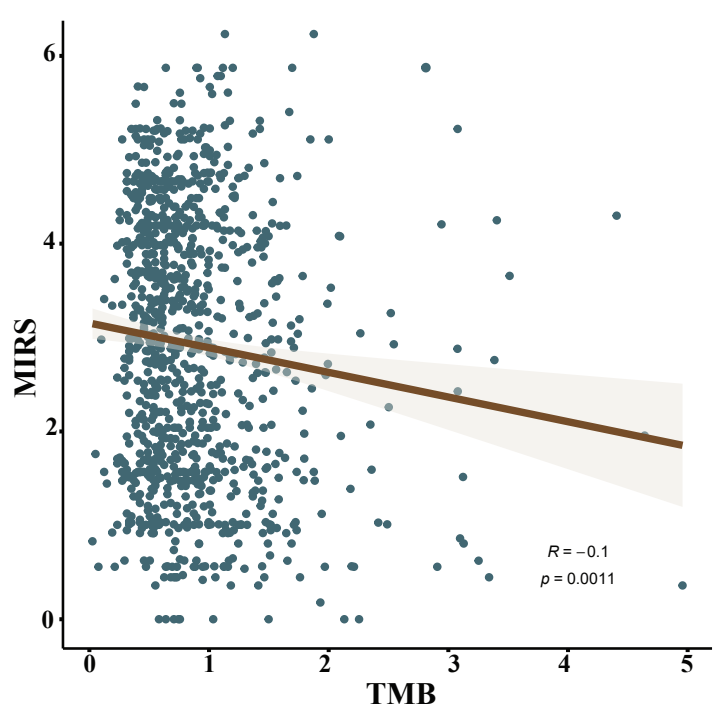


medRxiv preprint doi: https://doi.org/10.1101/2021.12.16.21267775; this version posted December 17, 2021. The copyright holder for this

A

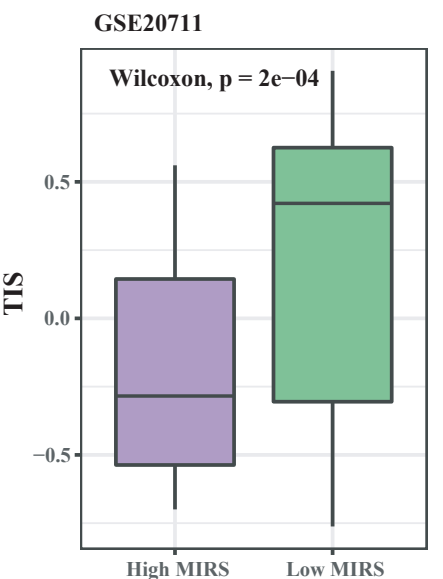

B

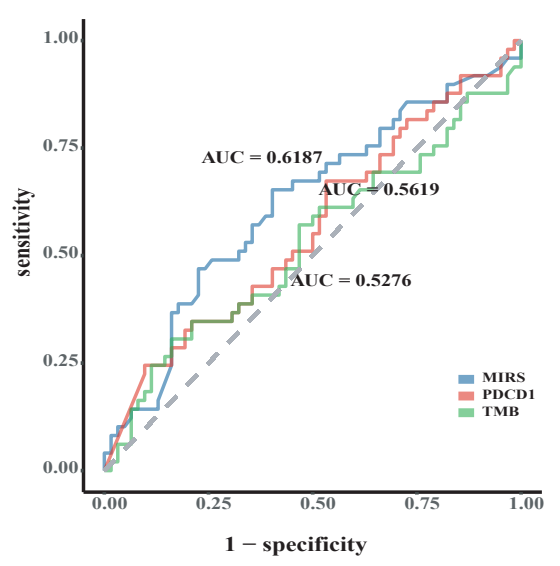

E

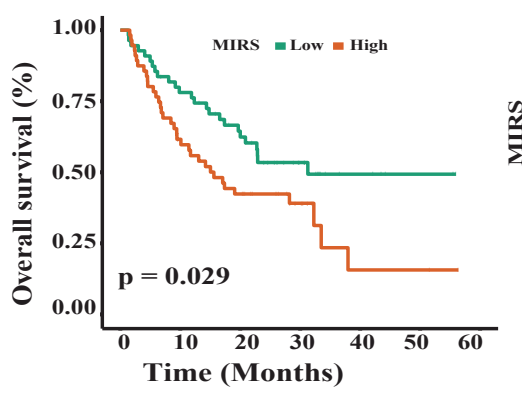

I

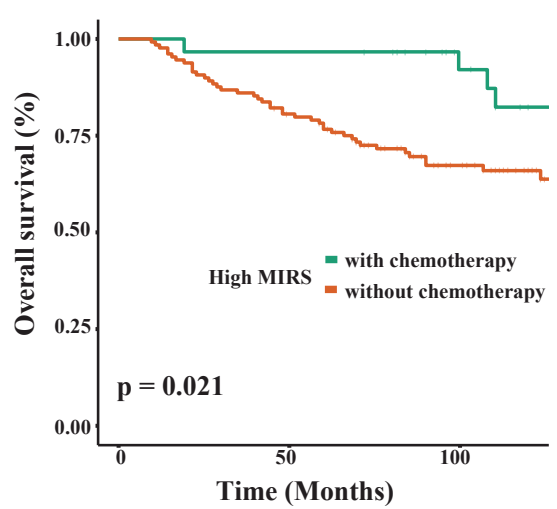

$\mathbf{K}$

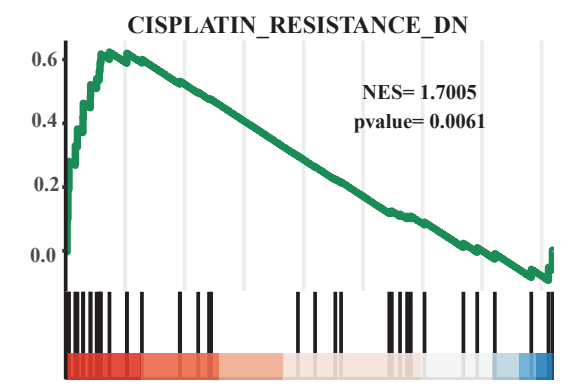

AfSEzR711

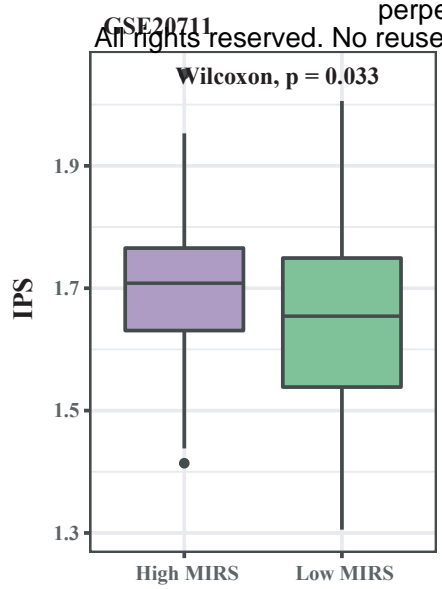

C

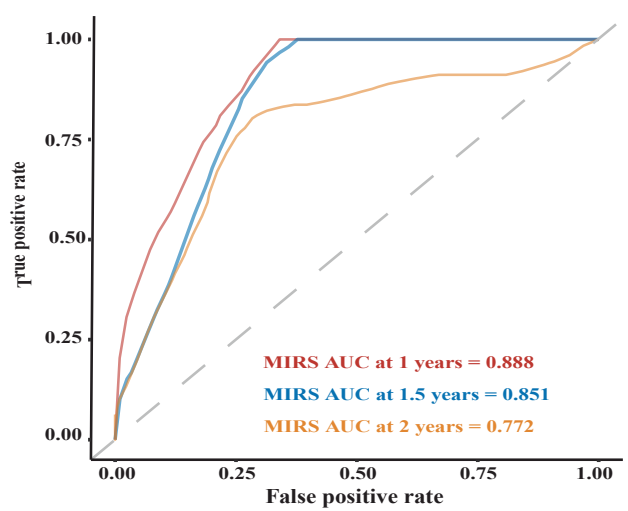

G

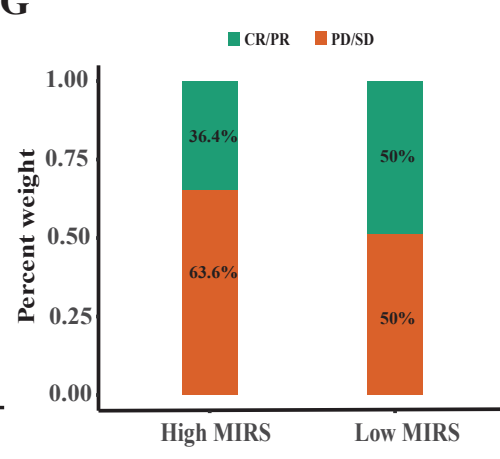

L

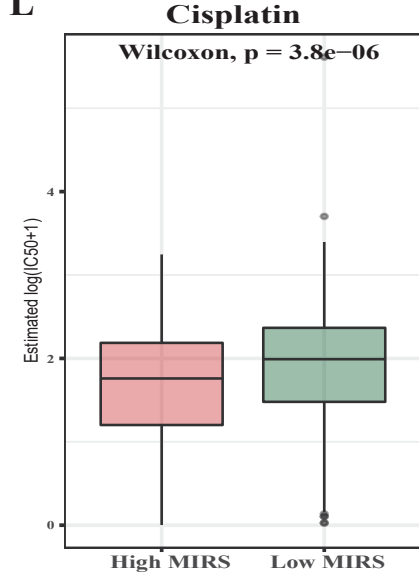

J

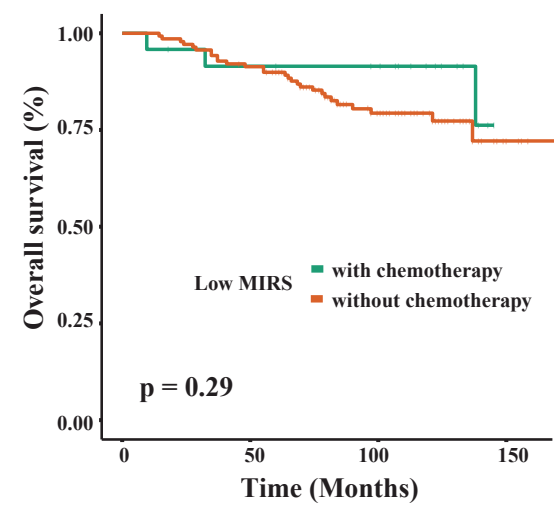

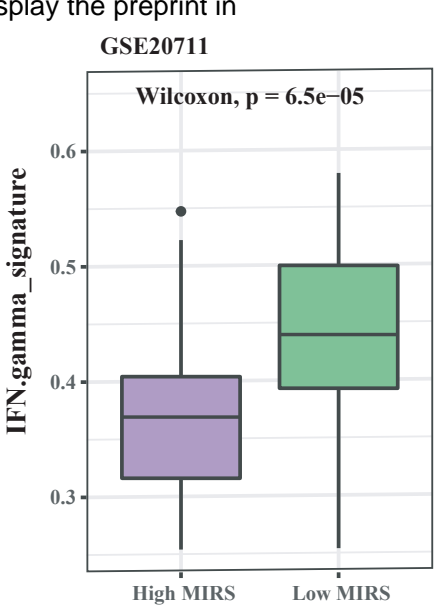

D

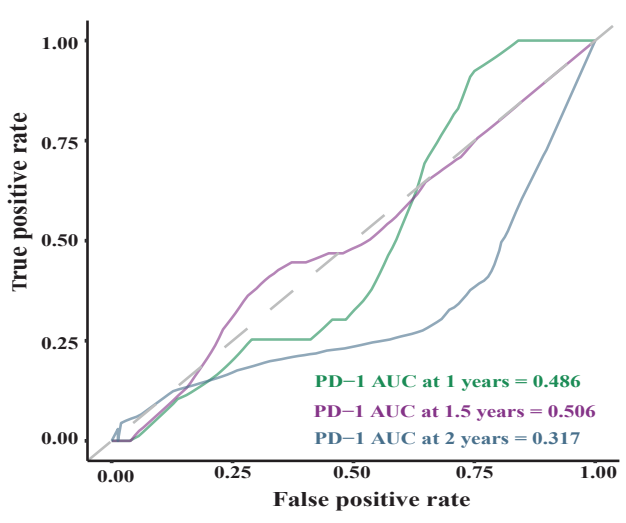

H

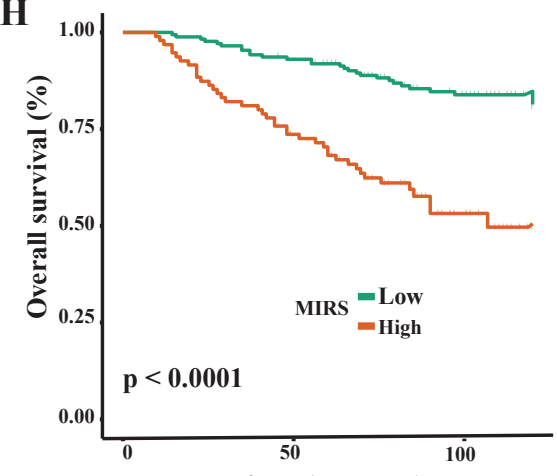

Time (Months)

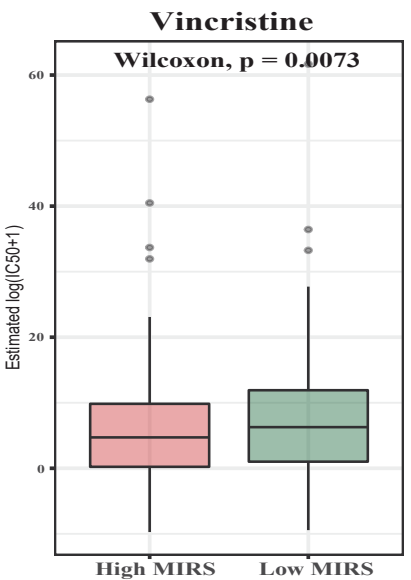

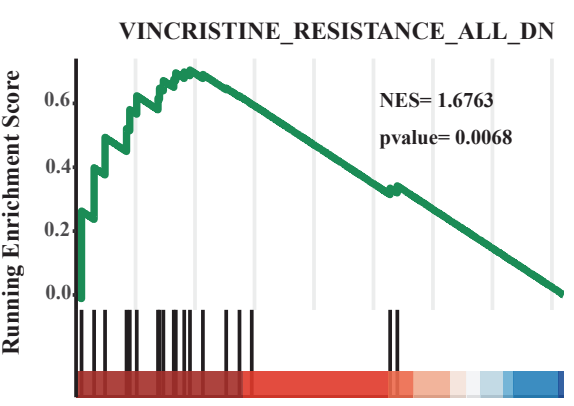

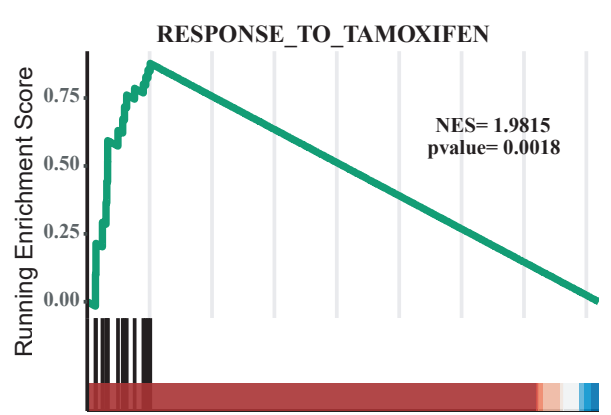


medRxiv preprint doi: https://doi.org/10.1101/2021.12.16.21267775; this version posted December 17,2021 . The copyright holder for this preprint (which was not certified by peer review) is the author/funder, who has granted medRxiv a license to display the preprint in perpetuity.

A All rights reserved. No reuse allowed without permission.

\section{MIRS}

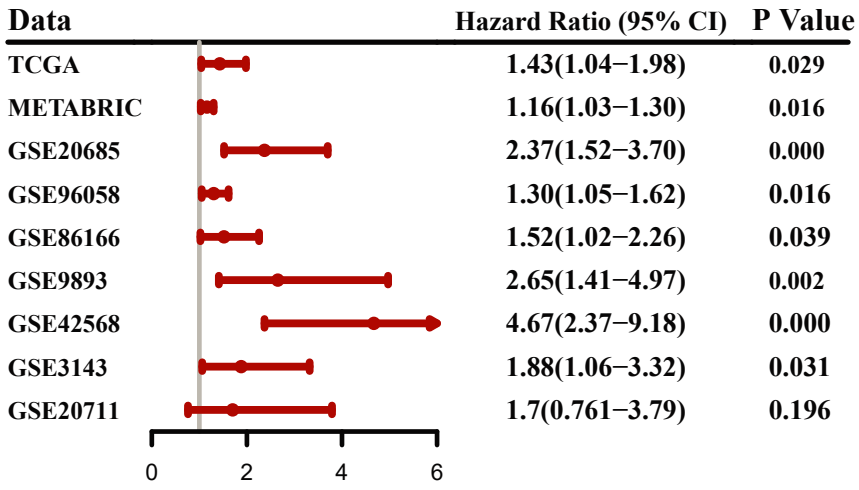

C

Hazard Ratio

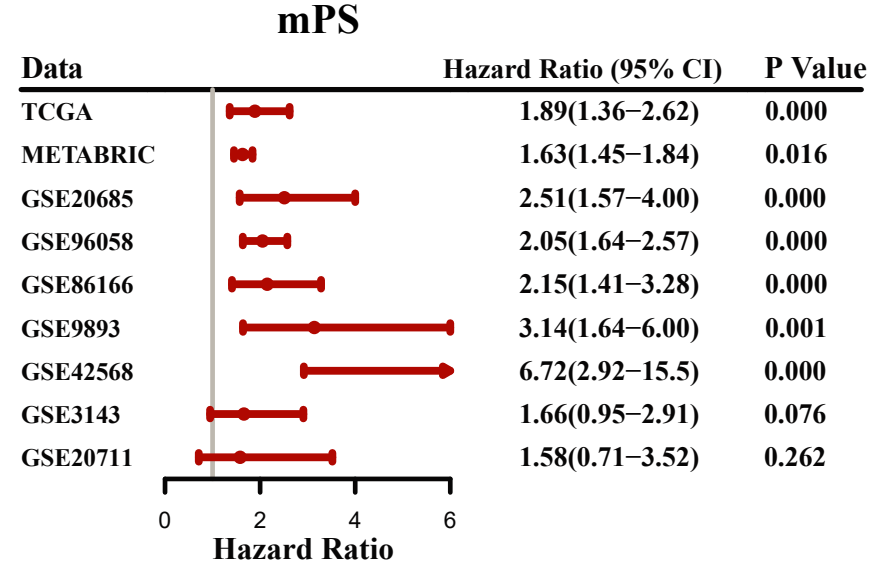

D

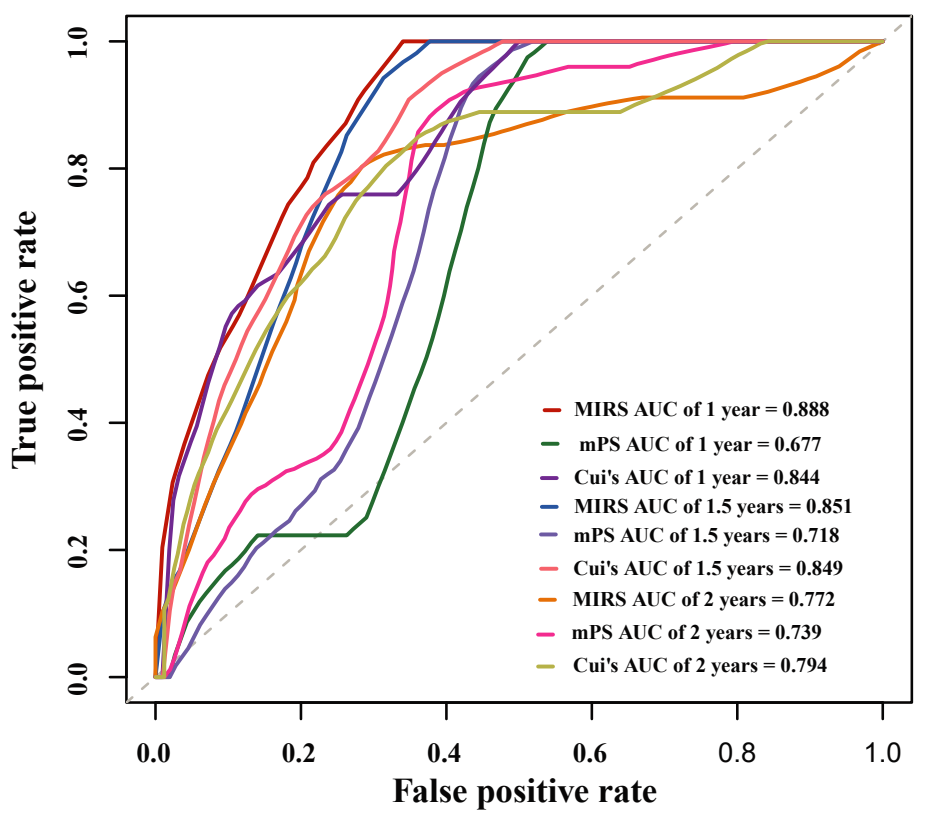

$\mathbf{E}$

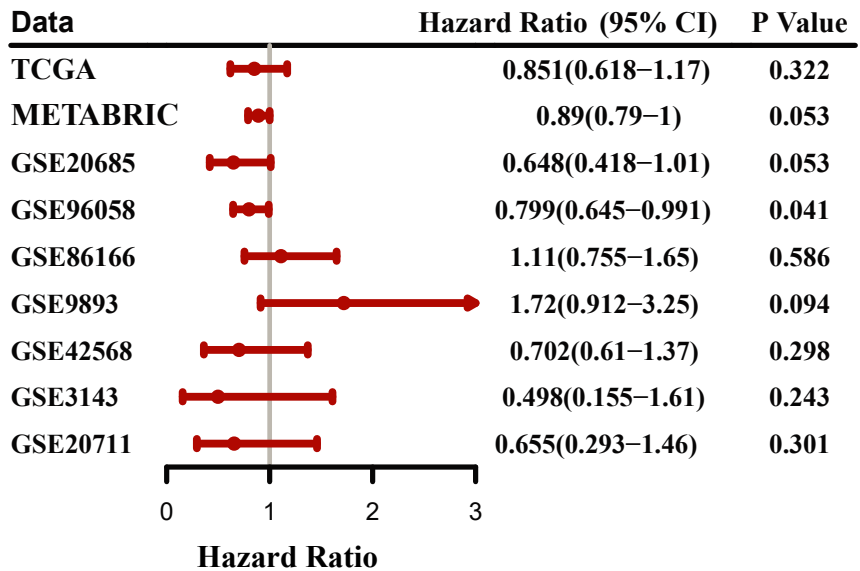
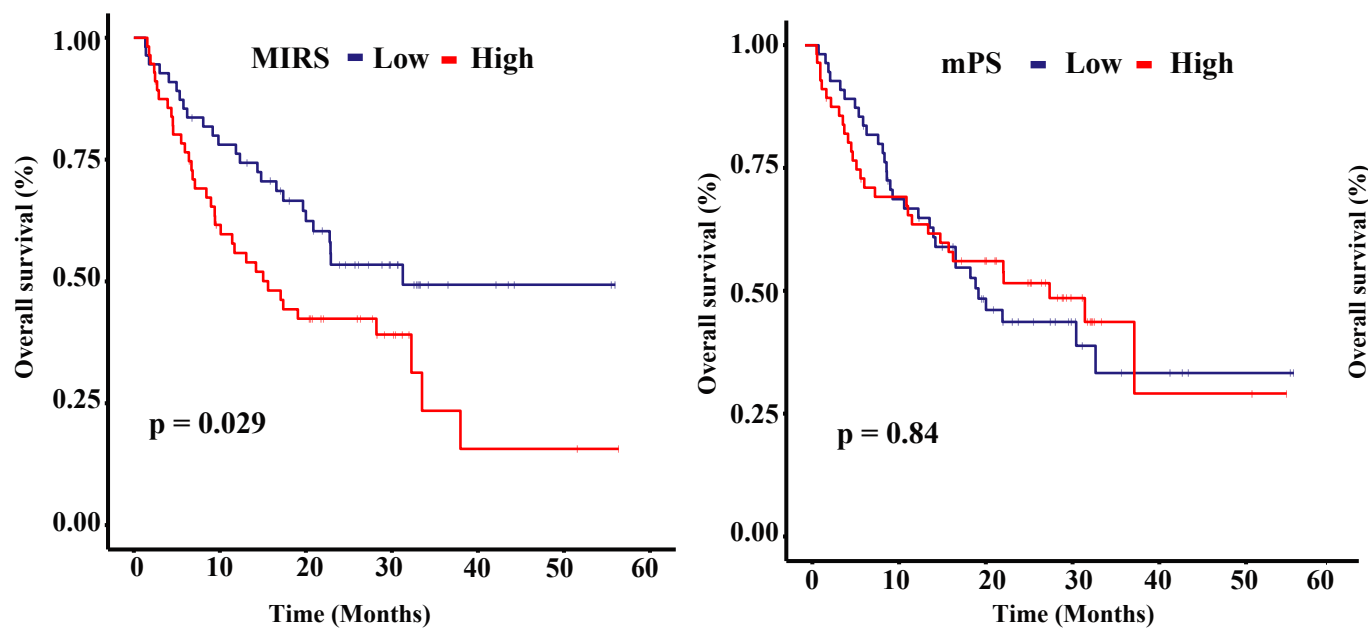